\title{
Principles of Competence: The Ability of Public Institutions to Adopt Remedial Affirmative Action Plans
}

Public institutions frequently adopt affirmative action plans that grant preferential treatment to individuals on the basis of their membership in a minority group. Many of these plans are designed to remedy earlier violations of the antidiscrimination laws. Despite this benign purpose, individuals not eligible for preference may challenge the plans as explicit racial classifications prohibited by the fourteenth amendment. Such cases contain a vexing irony: government action aimed at remedying illegal discrimination is itself alleged to be discriminatory and illegal.

Under the Supreme Court's current approach to equal protection issues, the government's ability to adopt race-conscious plans depends on a showing of "compelling" government interest. ${ }^{1}$ Such plans may serve a variety of "nonremedial" interests, such as fostering diversity or promoting greater operational effectiveness through integration. ${ }^{2}$ Often, however, the remedying of past discrimination is the central or even the sole interest claimed to be

3 A majority of the Supreme Court now seems to review race-conscious affirmative action plans under a standard of strict scrutiny, requiring a "compelling" governmental interest before they may be adopted. See Wygant v. Jackson Bd. of Educ., 106 S. Ct. 1842, 1846 (1986) (plurality opinion); id. at 1852-54 (O'Connor, J., concurring); Fullilove v. Klutznick, 448 U.S. 448, 491 (1980) (opinion of Burger, C.J., joined by White, J.); see also infra note 9 (describing levels of scrutiny). In the past, however, the Justices have often differed on this question, some requiring that the interest be "compelling," see Fullilove v. Klutznick, 448 U.S. 448, 507 (1980) (Powell, J., concurring); id. at 552 (Stevens, J., dissenting), others "important," Fullilove, 448 U.S. at 519 (Marshall, J., concurring); University of California Regents v. Bakke, 438 U.S. 265, 359 (1978) (Brennan, J., concurring). In the plurality opinion in Fullilove, Chief Justice Burger refused to define which standard of scrutiny applied, although he indicated in that case that the government's interest was sufficient to survive even the strictest scrutiny. 448 U.S. at 492.

2 These government interests, apart from the remedying of past discrimination, may be sufficiently compelling to warrant the use of explicit racial classifications. For instance, in Bakke, Justice Powell accepted the goal of diversity in education as compelling. See 438 U.S. at 311-15 (Powell, J.); see also Wygant, $106 \mathrm{~S}$. Ct. at 1853 (O'Connor, J. concurring). But see Mississippi Univ. for Women v. Hogan, 458 U.S. 718, 731 n.17 (1982) (rejecting diversity as a compelling interest). Other interests, such as the need to integrate a police force in order for it to function more effectively, might also be compelling. This comment, however, focuses on race-conscious plans that serve a remedial purpose. 
served by such a plan. ${ }^{3}$ If this claim is rejected by the courts, all that remains is an unjustified classification based on race. The focus of this comment is the question thus raised: When should courts accept a public institution's claim that a race-conscious plan serves the government's interest in remedying past discrimination?

Courts facing remedial affirmative action plans have diverged widely in their analyses. For example, two separate panels of the Ninth Circuit have reached opposite results in evaluating the ability of a school board to adopt remedial affirmative action measures in the granting of contracts. ${ }^{4}$ Part I of this comment reviews several different approaches emerging from the Supreme Court's decisions on affirmative action, and then traces the resulting disagreement and confusion among the lower courts.

Part II then argues that a unifying principle for evaluating government claims that race-conscious programs are aimed at remedying past discrimination can be found in the idea of institutional competence. Using the example of congressional action, this part identifies two distinct aspects of competence: the authority of the institution to adopt an affirmative action plan, and the findings of fact made by the institution which indicate past violations of the antidiscrimination laws. When both aspects of competence are present, it is likely that the institutional decision to adopt a raceconscious plan furthers a sufficiently compelling purpose and was not motivated by an impermissible desire to benefit one group more than another solely on the basis of race.

Part III applies this concept of competence to various public institutions. It concludes that, like Congress, state legislatures have a broad capacity to adopt remedial affirmative action plans; local representative bodies are competent in a similar but somewhat narrower range of circumstances. Administrative agencies may also possess such power, depending on the institution's particular characteristics. Once the necessary authorization is shown and appropriate findings have been made, a court should hold that the government has demonstrated a compelling interest, and need only review the plan to determine whether or not it actually serves that

3 The Supreme Court has rejected the remedying of unspecified "societal discrimination" as a sufficiently compelling governmental interest for adopting an affirmative action plan. See Wygant, $106 \mathrm{~S}$. Ct. at 1847-48 (plurality opinon); id. at 1854 (O'Connor, J., concurring); id. at 1857 (White, J., concurring); see also infra note 103.

- Compare Associated Gen. Contractors v. San Francisco Unified School Dist., 616 F.2d 1381 (9th Cir.) (rejecting school board affirmative action contract grant plan), cert. denied, 449 U.S. 1061 (1980), with Schmidt v. Oakland Unified School Dist., 662 F.2d 550 (9th Cir. 1981) (approving similar plan), vacated, 457 U.S. 594 (1982). 


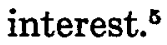

\section{The Problem of Affirmative Action}

The fourteenth amendment commands that no state shall deny any person the equal protection of the laws. ${ }^{6}$ In scrutinizing government acts that classify and distinguish among individuals, the courts have interpreted the equal protection clause as a requirement that "similar individuals . . . be dealt with in a similar manner by the government." Impermissible treatment contrary to this command is most likely to occur when the government activity is motivated by an improper government purpose, such as prejudice. ${ }^{8}$ Consequently, the courts have subjected government actions to more searching inquiry when the likelihood is greater that the acts were impermissibly motivated. ${ }^{9}$

- The question of how closely the plan adopted meets its objectives is classically called the "means-end fit." In the language of the Supreme Court, the plan must be "narrowly tailored" to its alleged objectives. See Wygant, $106 \mathrm{~S}$. Ct. at 1846-47, 1849-50 (plurality opinion); id. at 1853, 1857 (O'Connor, J., concurring); Fullilove, 448 U.S. at 480 (plurality opinion); see also infra note 9 (describing levels of scrutiny). How narrowly tailored the plan must be is discussed briefly infra note 174 . Yet this comment primarily addresses the logically distinct and antecedent question of when a public institution establishes a government interest sufficient to justify the adoption of a race-conscious remedial plan.

- U.S. Const. amend. XIV, \& 1.

7 J. Nowak, R. Rotunda \& J. Young, Constitutional Law 586 (2d ed. 1983).

- Id. (motive analysis "does not reject the government's ability to classify persons . . . but it does guarantee that those classifications will not be based upon impermissible criteria or arbitrarily used to burden a group of individuals").

- Since the Supreme Court's decision in United States v. Carolene Products, 304 U.S. 144, 152 n.4 (1938), courts have stringently examined classifications directed at "discrete and insular minorities." Such legislative classifications deserve heightened scrutiny because the political process is more likely to have been motivated by impermissible purposes, such as prejudice, when classifications are directed at insular groups. Thus, a court will not uphold such acts unless they serve a "compelling interest" of the government and unless the means chosen are "narrowly tailored" to achieve that purpose. See, e.g., Fullilove v. Klutznick, 448 U.S. 448, 507 (1980) (Powell, J., concurring). Because very few statutes subjected to strict scrutiny have been upheld, such intense review has been called " 'strict' in theory, and fatal in fact." See Gunther, In Search of Evolving Doctrine on a Changing Court: A Model for a Newer Equal Protection, 86 HARv. L. Rev. 1, 8 (1972).

In contrast, classifications that have no special impact on politically powerless minority groups or on the exercise of a fundamental right need only be reasonable to survive judicial review. See, e.g., Williamson v. Lee Optical, 348 U.S. 483, 488-88 (1955). Under this rationality review, the classification need only be a reasonable means of attaining a legitimate government interest.

Finally, intermediate scrutiny is used in the middle cases where a classification is directed at an insular group but where there are certain reasons that may justify some differentiation. Under this level of scrutiny a classification must be based on an "important" governmental interest and be "substantially related" to its goal. See, e.g., Craig v. Boren, 429 U.S. 190, 197 (1976) (applying intermediate scrutiny to classifications based on sex).

It should be noted that the analysis in this comment does not depend on what level of 
Affirmative action plans, which inherently involve explicit racial classifications, pose some danger of impermissible motivation. Yet affirmative action plans often have a remedial aim which, in contrast to bare prejudice, 'could constitute a valid government interest for instituting the plan. The Supreme Court has found that the government's interest in remedying the effects of a violation of the antidiscrimination laws is "compelling." 10 But since the government may assert a past violation to conceal actual motives that are impermissible, the courts need some way to distinguish true assertions from false ones. Thus the crucial step in validating a race-conscious plan is establishing a proper foundation for concluding that the plan has a remedial component. ${ }^{11}$ But in the absence of a judicial determination that the antidiscrimination laws have been violated, ${ }^{12}$ it is unclear when other government bodies may adopt affirmative action plans and whether their own findings of illegal discrimination can serve as the basis for such plans.

Current court doctrine provides little aid in resolving this issue. The Supreme Court's decisions have produced no less than five distinct positions. Faced with this uncertainty, the lower courts have struggled on the way to further disagreement and con-

scrutiny the courts apply in examining remedial affirmative action plans. If an institution is judged "competent" to institute such plans, it makes out a sufficiently compelling government interest for its action. A fortiori, the adoption of such plans by a competent institution meets the "government interest" prong of any lower level of scrutiny as well. For a brief discussion of the appropriate standard of scrutiny for cases involving remedial affirmative action plans, see infra note 174 .

10 See Swann v. Charlotte-Mecklenburg Bd. of Educ., 402 U.S. 1 (1971) (district court may use racial statistics to formulate a remedial plan); Green v. County School Bd., 391 U.S. 430 (1968) (school boards have an affirmative duty to eliminate discrimination "root and branch"). In addition, the Court's busing cases confirm that remedial needs justify burdening innocent parties. See Columbus Bd. of Educ. v. Penick, 443 U.S. 449 (1979); Dayton Bd. of Educ. v. Brinkman, 443 U.S. 526 (1979).

For the purposes of this comment, the "antidiscrimination laws" include all constitutional and statutory provisions prohibiting discrimination; hence, both the equal protection clause of the fourteenth amendment and the civil rights statutes, for example, fall into this category.

11 When a government body justifies its adoption of an affirmative action plan with reference to nonremedial interests, such as the fostering of diversity, the Court's approach will be analytically simpler than it is for a remedial plan. Since, by hypothesis, the plan is nonremedial, findings of prior discrimination become irrelevant. The sole issue is whether the nonremedial interest put forward to justify the plan is found to be sufficiently important or compelling to justify the racial classification. Beyond that issue, judicial review is limited to determining whether the plan adopted in fact properly advances the interests identified.

22 The law is clear that a judicial finding of past illegal discrimination provides a compelling government interest in eliminating that discrimination and its effects. See, e.g., Brown v. Board of Educ., 347 U.S. 483 (1954); Franks v. Bowman Transp. Co., 424 U.S. 747 (1976); Teamsters v. United States, 431 U.S. 324 (1977). Such a finding therefore justifies the use of explicit racial classifications to achieve that remedial objective. 
fusion. This part presents the major opposing views in order to set the stage for further discussion.

\section{A. Supreme Court Jurisprudence}

In University of California Regents $v$. Bakke, ${ }^{13}$ a deeply divided court determined that a racial classification adopted by the California Board of Regents, which established a separate minority track for admission to medical school, violated the fourteenth amendment. ${ }^{14}$ Conversely, in Fullilove v. Klutznick, ${ }^{15}$ the Court divided in upholding an affirmative action program enacted by Congress for minority business enterprises. ${ }^{16}$ Most recently, in Wygant v. Jackson Board of Education, ${ }^{17}$ the Court again divided in striking down a race-conscious layoff plan adopted by a school board as part of its collective bargaining agreement with the teachers' union. ${ }^{18}$ The opinions in these cases offer five separate approaches to the question of when a government institution may adopt affirmative action in the absence of a judicial finding of illegal past discrimination.

1. Polar Positions. Justice Brennan's concurring opinion in Bakke and Justice Stewart's dissent in Fullilove set out two polar

33438 U.S. 265 (1978).

14 The affirmative action plan at the University of California at Davis Medical School consisted of a two-track admissions program. Sixteen of the 100 positions available were reserved for minority applicants. Those applicants did not have to compete with the applicants in the general admissions program. Id. at 275. Justice Powell wrote for the Court. Justice Brennan's concurrence spoke for four members of the Court. The three other Justices joined Justice Stevens' dissent, which did not reach the constitutional question. Id. at 408.

1s 448 U.S. 448 (1980).

16 The minority business enterprise provisions of the Public Works Employment Act of 1977, Pub. L. No. 95-28, 91 Stat. 116 (codified at 42 U.S.C. $\$ 6701$ (1982)), amending Local Public Works Capital Development and Investment Act of 1976, Pub. L. No. 94-369, 90 Stat. 999, required at least $10 \%$ of federal funds granted for local public works projects to be used by the state or local grantee to procure services or supplies from businesses owned by minozity group members, absent an administrative waiver. Minority-group members included United States citizens who were "Negroes, Spanish-speaking, Orientals, Indians, Eskimos and Aleuts." 42 U.S.C. § 705(f)(2). In Fullilove, Justice Burger wrote a plurality opinion, in which Justices White and Powell joined. Justice Powell and Justice Marshall each concurred separately, with Justices Brennan and Blackmun joining Justice Marshall. Justice Stevens and Justice Stewart wrote in dissent.

17106 S. Ct. 1842 (1986).

13 The collective bargaining agreement provided that layoffs of teachers would be made according to seniority, except that "at no time will there be a greater percentage of minority personnel laid off than the current percentage of minority personnel employed at the time of the layoff." Id. at 1845 (plurality opinion). Justice Powell wrote for the plurality, which included Chief Justice Burger and Justice Rehnquist. Justices White and O'Connor concurred, while Justices Brennan, Marshall, Blackmun, and Stevens wrote in dissent. 
visions of government competence. While Justice Brennan would allow most government institutions to enact affirmative action plans, Justice Stewart's view allows only impartial and deliberative bodies-such as courts-to adopt explicit racial classifications.

In Bakke, Justice Brennan articulated a broad conception of government competence. He argued first that a judicial finding of racial discrimination was not a necessary predicate to an affirmative action plan because requiring such a finding would frustrate voluntary compliance with the antidiscrimination laws. ${ }^{19} \mathrm{He}$ also stated that proof that benefited individuals had been actual victims of past discrimination was not required in the case of "historically disadvantaged minorities" who are within a "general class of persons likely to have been the victims of discrimination." requisite harm to individual minority group members could be inferred from the broader historical context of discrimination in America. Thus, Justice Brennan concluded, a finding of past discrimination against a disadvantaged minority by a government institution was not crucial to the institution's ability to adopt an affirmative action plan. ${ }^{21}$

Drawing on several cases that emphasized similar concerns when congressional action was involved, ${ }^{22}$ Justice Brennan then concluded that specific findings were unnecessary for the adoption of affirmative action plans by the states. But he did not limit this conclusion to state legislatures, which are the clear analogues to Congress. Instead, he noted that generally a state could delegate functions within its governing structure however it chose. ${ }^{23}$ Thus, in Bakke he determined that the California Constitution's grant to the Regents of plenary legislative and administrative power over the state university system constituted sufficient authorization to permit them to adopt a race-conscious admissions program without a prior finding of a discriminatory violation. ${ }^{24}$

19438 U.S. at 364 (Brennan, J., concurring, joined by White, Marshall \& Blackmun, JJ.). Justice O'Connor holds a similar view. See infra note 53.

20 Id. at 363.

21 Id. at $366 \&$ n.42.

22 Id. at 366; see, e.g., United Jewish Orgs. v. Carey, 430 U.S. 144, 161 (1977) (plurality opinion); McDaniel v. Barresi, 402 U.S. 39 (1971); cf. Califano v. Webster, 430 U.S. 313, 317 (1977) (citing the "important governmental objective" of reducing "the disparity in economic condition between men and women caused by the long history of discrimination" to justify preferential benefits system).

${ }_{23} 438$ U.S. at 366 n.42; cf. Sweezy v. New Hampshire, 354 U.S. 234, 256 (1957) (Frankfurter, J., concurring) (whether persons in the executive, legislative or judicial branch may exercise the powers of another department is for the determination of the state).

24438 U.S. at $366-67 \&$ n.42. 
Under Justice Brennan's test in Bakke, a government institution may adopt a remedial affirmative action plan as long as it has been given broad discretionary power to administer a government activity. In his view, this general power to administer some activity implicitly includes the full power to adopt affirmative action plans. No specific findings of past discrimination are necessary when "there is reason to believe that the evil addressed is a product of past racial discrimination."

The other end of the spectrum emerges with Justice Stewart's dissent in Fullilove: explicit racial classifications may be imposed only by a court. ${ }^{26} \mathrm{He}$ conceded that a violation of the antidiscrimination laws creates a sufficiently compelling government interest to justify the use of explicit racial classifications. ${ }^{27}$ Yet he suggested that only an impartial, deliberative body could find violations of law and craft a remedy that distributed benefits to those identified as victims of the violation. ${ }^{28}$ The courts meet this criterion of deliberative impartiality. Legislatures, in contrast, have "neither the dispassionate objectivity nor the flexibility that are needed to mold a race-conscious remedy around the single objective of eliminating the effects of past or present discrimination."29

Although Justice Stewart acknowledged Congress's explicit authority to enact legislation enforcing the fourteenth amendment, ${ }^{30}$ he argued that such authority is limited to enactments which would remedy specific injuries. In his view, Congress's ability to legislate enforcement of the fourteenth amendment gives it no greater power than the judiciary to make racial classifications. Therefore, because Congress lacks the adjudicatory capabilities necessary to find violations of the law and adopt remedial programs, remedial affirmative action plans may remain beyond even Congress.

2. Middle Ground. Between these two positions lie the closely related views of Justices Stevens, Powell, and O'Connor. Each Justice considers both the authority of a public institution

2s Id. at 366. Justice Brennan, along with Justices Marshall and Blackmun, has continued to rely on this formulation of the proper standard for evaluating affirmative action plans. See Wygant, $106 \mathrm{~S}$. Ct. at 1861-63 (Marshall, J., dissenting).

${ }^{28} 448$ U.S. at 522 (Stewart, J., dissenting).

27 Id. at 525 n.4.

${ }^{38}$ Id. at 527 .

20 Id. Justice Stewart went on to argue, however, that the plan was invalid "even assuming" Congress had the authority to implement it because it did not have the "sole purpose" of remedying past discrimination. $I d$. at 527-28.

so Id. at 526; see U.S. Const. amend. XIV, § 5 ("The Congress shall have power to enforce, by appropriate legislation, the provisions of this article."). 
and its ability to make findings of past discrimination important in determining the institution's competence to impose remedial plans. Each agrees that institutions other than courts may adopt such plans. They differ principally in the nature of the findings they require of governmental bodies.

Justice Stevens argues that government institutions of all sorts may be able to adopt remedial plans. In order to do so, however, the authorizing provision must be unmistakably clear. Such clarity might arise if the adoption of a remedial plan is "expressly mandated by Congress or the President," or if the "agency which promulgates the rule has direct responsibility for fostering or protecting" the government's interest in remedying illegal discrimination. ${ }^{31}$ In his Fullilove dissent, Justice Stevens acknowledged that Congress has the power to enact race-based remedial measures. ${ }^{32}$ But he did not discuss whether this power may be exercised by other government organs absent express authorization.

Moreover, in Justice Stevens' view, even authorized institutions must show that they carefully considered their decision to adopt a race-conscious plan. For "just as procedural safeguards are necessary to guarantee the impartial decisionmaking in the judicial process, so can they play a vital part in preserving the impartial character of the legislative process." ${ }^{33}$ Applying this analysis in

31 Hampton v. Mow Sun Wong, 426 U.S. 88, 103 (1976) (emphasis added). In Hampton, Justice Stevens struck down a Civil Service Commission employment rule that classified persons upon the basis of alienage. One of the grounds for decision was a concern that one of the government interests behind such a rule, to effectuate foreign policy objectives, was not within the Commission's authorization. Id. at 114-17. The analysis in Hampton is somewhat inapposite since it was not an equal protection case, strictly speaking, and its reasoning pertained to the adoption of a rule which disadvantaged minority groups. Since Justice Stevens considers any racial classification to be suspect, however, see Fullilove, 448 U.S. at 533-35 (Stevens, J., dissenting), his position in Hampton relates directly to his analysis of affirmative action plans. Justice Powell, too, stressed the importance of Hampton by citing it repeatedly in his Bakke opinion. See 438 U.S. at 302 n.41, 309.

${ }^{32}$ See Fullilove, 448 U.S. at 548-49 \& n.23 (acknowledging congressional power to enact "statutory classification[s] based on race"); cf. Hampton, 426 U.S. at 114 (assuming that Congress and the President have equal authority to create alien classifications).

ss Fullilove, 448 U.S. at 549; accord id. at 552 (Congress failed to "follow procedures that guarantee the kind of deliberation that a fundamental constitutional issue of this kind obviously merits"); Linde, Due Process of Lawmaking, 55 NEB. L. REv. 197, 255 (1976); Sager, Insular Majorities Unabated: Warth v. Seldin and City of Eastlake v. Forest City Enterprises, Inc., 91 HARv. L. REv. 1373, 1414 (1978) (Hámpton "posits a right to procedural due process which requires that some legislative actions be undertaken only by a governmental entity which is so structured and so charged as to make possible a reflective determination that the action contemplated is fair, reasonable, and not at odds with specific prohibitions in the Constitution"). This analysis has been labelled "structural due process." See Laurence Tribe, American Constitutional Law $\$ \S 17-1$ to -3 (1978); Tribe, Structural Due Process, 10 HaRv. C.R.-C.L. L. Rev. 269, 299-303 (1975). 
Fullilove, he voted to strike down the minority set-aside program because the record was inadequate to prove that Congress deliberated about the need for such a program. Unlike Justice Stewart, however, he did not despair of institutional compliance with a stringent findings requirement. ${ }^{34} \mathrm{He}$ would uphold the adoption of a carefully tailored racial preference whenever the institution can show, by creating a sufficiently detailed, court-like record, that it has found a prior violation of the antidiscrimination laws. ${ }^{35}$

Justice Stevens continued to adhere to this view in Wygant. After scrupulously examining the procedures by which the school board had decided to adopt and implement a race-concious plan, ${ }^{36}$ he concluded that there was not a "shred of evidence [to] suggest[] any procedural unfairness in the adoption of the agreement."37 Thus, because he concluded that the government's policy of seeking a diverse faculty was sufficiently compelling, ${ }^{38}$ and because the plan was adopted only after careful consideration and the full participation of all those affected by it, Justice Stevens voted to uphold the challenged layoff plan.

Thus, for Justice Stevens, an institution's ability to adopt a remedial affirmative action plan is limited by the concepts of due process that he finds inherent in equal protection. A party is entitled to certain procedural safeguards before being burdened by state action. Equal protection requires that proper procedures be observed and that institutions enacting race-conscious measures make deliberative decisions before harming those excluded by the preference. $^{39}$

Justice Powell's opinions in Bakke and Fullilove set out a twoprong competence test similar to that of Justice Stevens. As he stated the test:

First, the governmental body that attempts to impose a raceconscious remedy must have the authority to act in response to identified discrimination. Second, the governmental body must make findings that demonstrate the existence of illegal discrimination. ${ }^{40}$

In Fullilove, Congress clearly had the necessary authority to

34 Fullilove, 448 U.S. at $550-51$ n.28.

${ }^{23}$ Id. at 538-39, 550-52.

so Wygant, $106 \mathrm{~S}$. Ct. at 1869-70 (Stevens, J., dissenting).

37 Id. at 1870 (emphasis in original).

ss Id. at 1868 .

so Fullilove, 448 U.S. at 550-52; see also supra note 33 (citing other authorities).

10448 U.S. at 498 (Powell, J., concurring) (citations omitted). 
adopt the minority set-aside program. Two explicit constitutional grants empowered it to enact race-conscious measures: the commerce clause and the enforcement provision of the fourteenth amendment. ${ }^{41}$ Moreover, he reasoned, a legislative body has broad power to make policy for the people it represents. ${ }^{42}$

In contrast, the Regents' "mission" in Bakke was restricted to educational matters. ${ }^{43}$ Justice Powell argued that the university was not authorized to remedy past discrimination other than its own because such broad measures were not within its delegated power. The limitation on the Regents' authority was required because "isolated segments of our vast governmental structures are not competent to make [affirmative action] decisions, at least in the absence of legislative mandates and legislatively determined criteria." "4

Justice Powell also required that even properly authorized institutions make findings of past statutory or constitutional violations before adopting a remedial plan. The body implementing the plan must have evidence that impermissible discrimination actually existed. Thus, he emphasized in Bakke that the Regents did "not purport to have made, and [were] in no position to make, such findings."

Although Justice Powell's language in Bakke sounds very similar to that of Justice Stevens, in Fullilove Powell made clear his

4 The plurality in Fullilove was also concerned with whether the minority set-asides were within the congressional spending power. Chief Justice Burger reasoned, though, that "[t]he reach of the Spending Power, within its sphere, is at least as broad as the regulatory powers of Congress." Id. at 475 (plurality opinion). The Court thereafter focused its analysis on the commerce clause and the enforcement provision of the fourteenth amendment.

42 Id. at 502 (Powell, J., concurring).

4s Bakke, 438 U.S. at 309 (Powell, J.).

14 Id. The Regents are a public corporation with responsibility for administering the affairs of the University of California system. They are "isolated" or lack accountability since they are not elected-vacancies are filled by the Governor. See O'Neil, Bakke in Balance: Some Preliminary Thought, 67 CALIF. L. REv. 143, 152 (1979). However, as Justice Brennan noted, several California court decisions have treated the Regents as empowered by the state constitution with full legislative authority. Bakke, 438 U.S. at 366-67 n.42 (Brennan, J., concurring).

45 U.S. at 309 (Powell, J.). On this basis, Justice Powell distinguished Bakke from earlier cases where the actions of the authorized institutions were predicated on "judicial, legislative or administrative findings of constitutional or statutory violations." Id. at 307 . In indicating approval of those earlier cases, see id. at 300-04, Justice Powell showed that he did not believe Congress alone was competent to adopt remedial plans. The cases he cited included United Jewish Orgs. v. Carey, 430 U.S. 144 (1977) (plan adopted by a state legislature), Contractors Ass'n v. Secretary of Labor, 442 F.2d 159 (3d Cir.) (plan adopted by an administrative agency), cert. denied, 404 U.S. 854 (1971), Carter v. Gallagher, 452 F.2d 315 (8th Cir. 1972) (plan adopted by a court), and Swann v. Charlotte-Mecklenburg Bd. of Educ., 402 U.S. 1 (1971) (plan adopted by a school board). 
disagreement with Justice Stevens' "due process of lawmaking" approach. Instead, he adopted a more traditional equal protection approach, which sought to ensure that the race-conscious plan was not premised on an impermissible motive. ${ }^{46}$ The requirement of deliberation and findings, he suggested, is a useful tool for screening out improper purpose. Yet this tool becomes less crucial when there are other guarantees that impermissible motives are absent.

In deciding that Congress's findings need not be exhaustive or set out in a court-like record, Justice Powell relied on such a guarantee: the legislative nature of Congress. He emphasized that Congress's "constitutional role is to be representative rather than impartial, to make policy rather than to apply settled principles of law." Congress has "special attribute[s] as a legislative body"-it can receive information from many different sources, and it can aggregate the experience it has acquired in addressing the problem of discrimination in different statutes over the course of many years. ${ }^{48}$ Thus, while he required that nonlegislative bodies such as the Regents make particularized findings, Justice Powell significantly relaxed the stringency of this requirement for Congress. $\mathrm{He}$ concluded that committee reports concerning earlier related legislation were sufficient to meet the standard.99

In his plurality opinion in Wygant, Justice Powell continued to emphasize the need for government institutions to make particularized findings before adopting an affirmative action plan. In the absence of such findings, he reasoned, "a court could uphold reme-

16 See supra notes $6-9$ and accompanying text.

47 Fullilove, 448 U.S. at 502; see also O'Neil, supra note 44, at 152 (interpreting Justice Powell's view to be that a "legislative body can be trusted more fully than can the Regents to take into account the competing claims of all groups seeking a preference. Accountability to the electorate is more readily assured").

48 Fullilove, 448 U.S. at 502-03. Justice Powell rejected Justice Stevens' suggestion, see id. at 553-54, that the Court must limit its scrutiny of congressional findings to those made in the legislative history of the bill at issue. Such an approach would ignore Congress's special ability to look beyond the facts brought before it by particular parties. Powell argued that the Court must not narrow Congress's broad investigatory powers if Congress is to carry out its obligation of fashioning "national rules for the governance of . . . society." Id. at 502. Moreover, Congress often develops an expertise from previously considering an issue; it may have much greater knowledge than the legislative history indicates. Id. at 502-03. Thus, Justice Powell emphasized the fact that several years earlier Congress had given detailed consideration to minority preference provisions in similar legislation. Id. at 504-05.

40 Fullilove, 448 U.S. at 502-06 (Powell, J., concurring). Chief Justice Burger also credited Congress with knowledge of past committee reports that had made findings of discrimination. Id. at 478 (plurality opinion). Although Powell and Burger's view apparently was the majority view, Fullilove might be interpreted, less plausibly, as requiring no congressional findings at all. The implications of such an approach are criticized infra at notes 94, 118-19 and accompanying text. 
dies that are ageless in their reach into the past, and timeless in their ability to affect the future." failed to make any determination that its layoff program was remedial, it had consistently denied that it had ever engaged in any discriminatory practices. ${ }^{51}$ In Justice Powell's view, the absence of any findings of past discrimination provided a sufficient ground to invalidate the plan. ${ }^{52}$

Justice O'Connor's concurrence in Wygant also reflected some attention to the issues of authority and findings. She argued that a competent government actor is not required to make findings of past discrimination before it adopts an affirmative action plan. ${ }^{53}$ Instead, she noted that contemporaneous findings serve only as a means of ensuring that the governmental actor is attempting to remedy its own past conduct and not generalized societal discrimination. When the public employer makes such findings voluntarily, they "obviously are desirable." Under Justice O'Connor's analysis, however, a remedial plan may be upheld even without particularized findings, as "long as the public actor has a firm basis for believing that remedial action is required."ss

\section{B. Lower Court Decisions}

This jumble of approaches offered by the Supreme Court has led to confusion in the efforts of state courts and lower federal courts to assess the validity of remedial plans. One of the lower courts' major problems stems from the difficulty they have in distinguishing between remedial and nonremedial plans, which has left their analysis of both kinds of plans hopelessly intertwined.66

so Wygant, $106 \mathrm{~S}$. Ct. at 1848.

${ }^{s 1}$ Id. at 1849,1852 n.13.

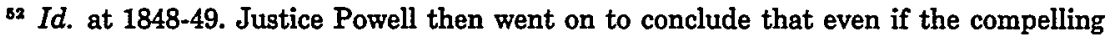
purpose of remedying past discrimination was demonstrated, layoffs would be an inappropriate means of effectuating that purpose; in the layoff context the burden borne by innocents is highly individualized and not spread among society. Id. at 1849-52.

ss Wygant, 54 U.S.L.W. at 1854-57 (O'Connor, J., concurring) (discussing the power of "the School Board, a court, or another competent body" to impose explicit racial classifications); see also id. at 1857 (plan was not constitutionally infirm simply because no particularized findings were made). The primary reason she gave for this conclusion was that a contemporaneous findings requirement would "severely undermine public employers' incentive to meet voluntarily their civil rights obligations." Id. at 1855 (citing Justice Brennan's opinion in Bakke, 438 U.S. at 364).

ot Id. at 1855.

ss Id. at 1853.

${ }^{\mathrm{B}}$ For a short explanation of why this state of affairs is problematic, see supra note 11 and accompanying text.

The lower courts have also struggled in the wake of the Supreme Court's confusion 
In addition, the courts have differed widely in their approaches to determining when government bodies can adopt remedial plans.

The courts universally agree that the President ${ }^{3 z}$ and the Congress $^{58}$ have the authority to adopt carefully-tailored race-conscious remedial plans. Yet this is the last point of uniformity. One district court has determined that only Congress can enact or grant other government institutions the power to enact a remedial plan,

about the appropriate level of scrutiny that should be applied to affirmative action plans. Some courts have adopted the intermediate-scrutiny standard suggested by Justice Brennan in his Bakke opinion. See, e.g., Bratton v. City of Detroit, 704 F.2d 878, 886 n.29 (6th Cir. 1983), cert. denied, 464 U.S. 1040 (1984); United States v. City of Miami, 614 F.2d 1322, 1338 (5th Cir. 1980); Detroit Police Officers' Ass'n v. Young, 608 F.2d 671, 694 (6th Cir. 1979), cert. denied, 452 U.S. 938 (1981); cf. Valentine v. Smith, 654 F.2d 503, 509 (8th Cir.) (employing a "searching examination" to determine validity of an affirmative action plan), cert. denied, 454 U.S. 1124 (1981). Several other courts have adhered to Justice Powell's stricter standard of scrutiny, requiring a plan to be "precisely tailored to serve a compelling governmental interest." Bakke, 438 U.S. at 299 (Powell, J.); see, e.g., Williams v. City of New Orleans, 729 F.2d 1554, 1561 (5th Cir. 1984); Local 35, IBEW v. City of Hartford, 625 F.2d 416, 421 (2d Cir. 1980), cert. denied, 453 U.S. 913 (1981); M.C. West, Inc. v. Lewis, 522 F. Supp. 338, 348 (M.D. Tenn. 1981); Arrington v. Associated Gen. Contractors, 403 So. 2d 893, 900 (Ala. 1981), cert. denied, 455 U.S. 913 (1982).

While a majority of courts have adopted one of these two approaches, several have adopted the mixed-factor standard of review crafted by Chief Justice Burger in Fullilove. This doctrine refuses to adopt any specific level of scrutiny and emphasizes a cluster of "factors" including the importance and validity of the remedial aim, the competence of the agency, and whether the remedy limits the burden suffered by innocent third parties. Fullilove, 448 U.S. at 453; see, e.g., Kromnick v. School Dist., 739 F.2d 894, 904 (3d Cir. 1984), cert. denied, 105 S. Ct. 782 (1985); South Fla. Chapter of the Ass'd Gen. Contractors of Am. v. Metropolitan Dade County, 723 F.2d 846, 851-52 (11th Cir.), cert. denied, 105 S. Ct. 220 (1984).

Finally, several courts confronted with the issue have confessed their confusion and simply refused to decide what level of scrutiny to apply. See Schmidt v. Oakland Unified School Dist., 662 F.2d 550, 560 (9th Cir. 1981), vacated on other grounds, 457 U.S. 594 (1982); Maehren v. City of Seattle, 92 Wash. 2d 480, 491, 599 P.2d 1255, 1262 (1979), cert. denied, 452 U.S. 938 (1981). For a brief discussion of how this comment's analysis bears on what level of scrutiny to apply, see infra note 174 .

57 See, e.g., United States v. New Orleans Pub. Serv., Inc., 553 F.2d 459 (5th Cir. 1977), cert. denied, 454 U.S. 892 (1981); Contractors Ass'n v. Secretary of Labor, 442 F.2d 159 (3d Cir.), cert. denied, 404 U.S. 854 (1971).

The President has acted primarily through Executive Order 11,246, 3 C.F.R. 339 (196465 compilation), reprinted in 42 U.S.C. $\$ 2000 \mathrm{e}$ (1976), amended by Exec. Order No. 12,086, 3 C.F.R. 230 (1978 compilation), which requires federal contractors to take "specific steps to guarantee equal employment opportunity [for] members of minority groups." 41 C.F.R. $\S 60-1.40$ (a) (1985). The executive order contains no specific presidential finding of past illegal discrimination to justify adoption of the plan. Utilizing Justice Jackson's analysis in Youngstown Sheet \& Tube Co. v. Sawyer, 343 U.S. 579, 634 (1952) (Jackson, J., concurring), courts have found the executive order to be within the President's power to act pursuant to congressional authorization. See NOPSI, 553 F.2d at 467 n.8; Contractors Ass'n, 442 F.2d at 168-71; see also Note, Executive Order 11,246 and Reverse Discrimination Challenges: Presidential Authority to Require Affirmative Action, 54 N.Y.U.L. Rkv. 376 (1979).

ss See Fullilove, 448 U.S. at 490-92. 
reasoning that Congress was uniquely authorized to address racial questions through its broad powers to regulate commerce and to enforce the fourteenth amendment. ${ }^{59}$ However, three federal appellate courts have rejected this interpretation, holding that Congress's unique power does not exclude state legislatures from authorizing such plans. ${ }^{60}$ Indeed, one of those courts went much further by interpreting the equal protection clause to require state legislatures to adopt remedial plans. ${ }^{61}$ Most other courts have been content to rely on the representativeness of state legislatures for implicit authorization. They emphasize the obvious parallel between the electoral accountability of state and federal legislatures. ${ }^{82}$

This emphasis on representation has been expanded by courts that have approved plans adopted by other representative bodies, such as county legislatures and city councils. Some courts have stressed that any electorally accountable institution is a "competent and responsible legislative body subject to political restraints." ${ }^{\text {"6s }}$ Other courts have ruled that local legislative bodies are

59 See Central Alabama Paving, Inc. v. James, 499 F. Supp. 629, 636-38 (M.D. Ala. 1980); see also Choper, The Constitutionality of Affirmative Action: Views from the Supreme Court, 70 KY. L.J. 1, 11-12 (1981-82). This view finds support in Justice Powell's reference to Congress' "unique constitutional power of legislating to enforce the provisions of the Thirteenth, Fourteenth and Fifteenth Amendments." Fullilove, 448 U.S. at 500 (Powell, J., concurring); see also id. at 483 (plurality opinion) ("It is fundamental that in no organ of government, state or federal, does there repose a more comprehensive remedial power than in Congress, expressly charged by the Constitution with competence and authority to enforce equal protection guarantees.").

so See e.g., Kromnick v. School Dist., 739 F.2d 894, 906 (3d Cir. 1984), cert. denied, 105 S. Ct. 782 (1985); South Fla. Chapter of the Ass'd Gen. Contractors of Am. v. Metropolitan Dade County, 723 F.2d 846, 852 (11th Cir.), cert. denied, 105 S. Ct. 220 (1984); Ohio Contractors Ass'n v. Keip, 713 F.2d 167, 172 (6th Cir. 1983) ("Though Justice Powell, in Fullilove referred to the power of Congress as 'unique,' we believe he meant the power was 'notable' or 'unequalled,' not 'sole' or 'exclusive." "); cf. Southwest Wash. Chapter of the Nat'l Elec. Contractors Ass'n v. Pierce County, 100 Wash. 2d 109, 122, 667 P.2d 1092, 1099 (1983) (en banc) (analogizing state police power to federal commerce power). Justice Powell's Bakke opinion indicates that he did not believe congressional authority was exclusive. See supra note 45.

61 See Ohio Contractors Ass'n v. Keip, 713 F.2d 167, 172 (6th Cir. 1983). Numerous courts have taken note of the implausibility of this logical inference. See, e.g., Associated Gen. Contractors v. San Francisco Unified School Dist., 616 F.2d 1381, 1388 (9th Cir.), cert. denied, 449 U.S. 1061 (1980); M.C. West, Inc. v. Lewis, 522 F.2d 338, 345 (M.D. Tenn. 1981) ("The tendency to turn the language of laws that require racial neutrality-thou-shalt-notdiscriminate laws-into authority for granting racial preference is twisting the plain meaning of statutes too far.").

${ }^{62}$ See, e.g., Michigan Road Builders Ass'n, Inc. v. Milliken, 571 F. Supp. 173, 178 (E.D. Mich. 1983) (characterizing the state legislature as the "ultimate policy making body" accountable to the public).

${ }^{63}$ Local 35, IBEW v. City of Hartford, 625 F.2d 416, 421 (2d Cir. 1980) (citation omit- 
authorized to act within the general concept of the police power, since the adoption of remedial affirmative action plans may improve the health and safety of the community by improving race relations. ${ }^{84}$ This justification is similar to the view that local remedial plans are authorized by county Home Rule Charters. ${ }^{60}$ Yet other courts have flatly refused to allow local public institutions to adopt remedial plans, arguing from Justice Powell's opinion in Bakke that these institutions are "isolated segments" of government. ${ }^{\text {Bs }}$

Although the lower courts have often discussed the authority by which elective public institutions act in adopting remedial plans, they have seldom considered the role of specific findings of past discrimination as a determinant of the reliability of the asserted remedial interest. ${ }^{6 z}$ This approach may reflect a plausible interpretation of Fullilove as having imposed no findings requirement on Congress. ${ }^{68}$ But this reading of Fullilove has not been expressly relied upon, and it is unclear whether the courts' various approaches may instead be the inevitable consequence of the Supreme Court's own confused precedents.

The range of opinion expands when the race-conscious plan

ted), cert. denied, 453 U.S. 913 (1981).

ot See, e.g., Hutchinson Human Relations Comm'n v. Midland Credit Mgmt., Inc., 213 Kan. 308, 311-12, 517 P.2d 158, 162 (1973); Southwest Wash. Chapter of the Nat'l Elec. Contractors Ass'n v. Pierce County, 100 Wash. 2d 109, 123, 667 P.2d 1092, 1099 (1983) (en banc).

es See South Fla. Chapter of the Ass'd Gen. Contractors of Am. v. Metropolitan Dade County, 723 F.2d 846 (11th Cir.), cert. denied, 105 S. Ct. 220 (1984). Provisions of a charter may, for example, permit a county to waive its low bid requirement for public contracts when the waiver is "in the county's best interests." Id. at 852. One such interest might be to remedy the effects of illegal past discrimination. This conception of "public interest" seems virtually identical to a broad conception of the police power. It differs only in that a state's police power is not statute-based while home rule powers of local governments may well be.

In seeking statutory authority for a local representative body to enact an affirmative action plan, at least one court found federal authorization, reasoning that Executive Order 11,246 , see supra note 57 , gives a city council receiving federal money the power to adopt a plan to remedy past discrimination. See Germann v. Kipp, 429 F. Supp. 1323, 1334-35 (W.D. Mo. 1977), vacated as moot, 572 F.2d 1258 (8th Cir. 1978) (en banc).

ce See, e.g., Arrington v. Associated Gen. Contractors of Am., 403 So. 2d 893, 901-02 (Ala. 1981) (refusing to permit a city council to adopt a remedial program), cert. denied, 455 U.S. 913 (1982).

67 Lower courts have often reduced the inquiry into competence to a simple inquiry into authorization. Very few courts have focused on the sufficiency of the findings made by the institution at this stage of their analysis. But see, e.g., Williams v. City of New Orleans, 729 F.2d 1554 (5th Cir. 1984) (en banc) (taking into account the findings made by the bodies promulgating the plan); Price v. Civil Serv. Comm'n, 26 Cal. 3d 257, 161 Cal. Rptr. 475, 604 P.2d 1365 (1980) (same).

See supra note 49 . 
was adopted by an unelected state or federal agency. ${ }^{69}$ Indeed, several commentators have argued that only representative bodies may adopt such plans because this kind of government action is at odds with democratic conceptions of equality. ${ }^{70}$ Most courts have permitted such action by nonlegislative bodies, however, at least when the delegating body has explicitly authorized the agency to enact affirmative relief. ${ }^{71}$ In that situation, the independent competence of the agency is not really at issue; the question is simply one of the scope of the authorization. ${ }^{72}$

The most troubling cases arise when the agency has adopted race-conscious plans without any explicit delegation of authority to do so. While some courts have concluded that the absence of specific authorization from a representative body is fatal, ${ }^{73}$ others

${ }^{60}$ The term "agency" is used here very broadly. It is meant to encompass any nonjudicial government body with a limited area of authority-in contrast to a legislative body-including, for example, civil service commissions, police boards, and contracting authorities. Most commonly, agency decisionmakers will be appointed rather than elected, though this is not always the case.

${ }^{70}$ See, e.g., Note, The Constitutionality of Affirmative Action in Public Employment: Judicial Deference to Certain Politically Responsible Bodies, 67 VA. L. REv. 1235, 1246 (1981) [hereinafter cited as Note, Judicial Deference]; Note, Fullilove v. Klutznick: Do Affirmative Action Plans Require Congressional Authorization?, 38 WASH. \& LEE L. REv. 1315, 1330-31 (1981).

71 This formulation skirts the question posed by the commentators: Should remedial authority ever be delegable? Most courts have concluded that it can be. See, e.g., United States v. New Orleans Pub. Serv., Inc., 553 F.2d 459, 467-68 n.8 (5th Cir. 1977) (approving Labor Department adoption of affirmative action rules pursuant to Executive Order 11,246), cert. denied, 454 U.S. 892 (1981); Contractors Ass'n v. Secretary of Labor, 442 F.2d 159, 171 (3d Cir.) (same), cert. denied, 404 U.S. 854 (1971). Similarly, authorization by state institutions is often explicit. See Associated Gen. Contractors v. Altshuler, 490 F.2d 9 (1st Cir. 1973) (approving agency affirmative action plan adopted pursuant to state executive order), cert. denied, 416 U.S. 957 (1974).

${ }^{32}$ Compare Central Alabama Paving, Inc. v. James, 499 F. Supp. 629 (M.D. Ala. 1980) (Department of Transportation lacks explicit authorization to adopt a plan conditioning receipt of federal highway funds on availability of grants to minority subcontractors), with M.C. West, Inc. v. Lewis, 522 F. Supp. 338 (M.D. Tenn. 1981) (Small Business Act provides requisite authority to adopt a similar plan); compare also Steele v. FCC, 770 F.2d 1192 (D.C. Cir. 1985) ("public interest" authorization of Federal Communications Act insufficient justification for licensing system which grants preferences to women), with id. at 1200 (Wald, J., dissenting) (diversity of viewpoint gained by increased female participation is sufficient public interest within meaning of statute to justify plan). See also Valentine v. Smith, 654 F.2d 503, $508 \mathrm{n} .9$ (8th Cir.) (finding in federal regulations the authority for university board of regents to enact an affirmative action plan), cert. denied, 454 U.S. 1124 (1981).

7s See, e.g., Steele v. FCC, 770 F.2d 1192, (D.C. Cir. 1985); Associated Gen. Contractors v. San Francisco Unified School Dist., 616 F.2d 1381, 1390 (9th Cir. 1980) ("the constitutionality and wisdom as social policy of [affirmative action] are sharply debatable, [and this] is precisely the kind of policy decision in which legislatures have the greatest advantage in competence over local agencies such as school boards"), cert. denied, 449 U.S. 1061 (1981). 
have developed additional justifications for dispensing with the need for express delegation, justifications which draw in part on the requirement that findings of past violations must be made.

First, several courts have ruled that school boards fall into a special category. ${ }^{74}$ They take Brown $v$. Board of Education ${ }^{75}$ to embody a judgment that the educational mission of school boards cannot be accomplished in the environment created by past actions constituting illegal discrimination. Brown itself is seen as a sweeping finding of pervasive de jure discrimination that authorizes school boards to remedy the problems by affirmative action..$^{76} \mathrm{On}$ this rationale, courts have approved plans fixing the ratio of black and white teachers, ${ }^{77}$ abolishing a promotional list for the position of principal to advantage minority applicants, ${ }^{78}$ and even using racial preferences in granting construction contracts. ${ }^{79}$

Another similar rationale adopted by some courts is that agencies always may adopt race-conscious plans to remedy their own past discriminatory practices. ${ }^{80}$ This power may be less controversial when, as with school boards, the only question a government body is permitted to address is whether it has discriminated de jure in the recent past. ${ }^{81}$ The Sixth Circuit has gone further, however, by permitting agencies to adopt race-conscious plans after having made their own findings of prior de facto discrimination. ${ }^{\mathbf{2}}$

7 See, e.g., Kromnick v. School Dist., 739 F.2d 894, 906-07 (3d Cir. 1984), cert. denied, 105 S. Ct. 782 (1985); Schmidt v. Oakland Unified School Dist., 662 F.2d 550, 559 (9th Cir. 1981), vacated on other grounds, 457 U.S. 594 (1982); Porcelli v. Titus, 431 F.2d 1254, 125758 (3d Cir. 1970), cert. denied, 402 U.S. 944 (1971).

73347 U.S. 483 (1954).

${ }^{78}$ Cf. Green v. County School Bd., 391 U.S. 430 (1968) (school boards operating [segregated] school systems were required by Brown II to " "effectuate a transition to a racially nondiscriminatory school system" ").

77 See, e.g., Kromnick, 739 F.2d at 894.

7s See, e.g., Porcelli, 431 F.2d at 1254.

70 See, e.g., Schmidt, 662 F.2d at 550. But see Associated Gen. Contractors v. San Francisco Unified School Dist., 616 F.2d 1381 (9th Cir. 1980) (rejecting an essentially identical plan as outside school board competence), cert. denied, 449 U.S. 1061 (1981). It is indeed difficult to see how the contracting process implicates the board's educational mission.

so See, e.g., Baker v. Detroit, 483 F. Supp. 930 (E.D. Mich. 1979), aff'd sub nom. Bratton v. Detroit, 704 F.2d 878 (6th Cir.), modified, 712 F.2d 222 (1983), cert. denied, 464 U.S. 1040 (1984).

s1 See McDaniel v. Barresi, 402 U.S. 39 (1971); see also infra notes 168-74 and accompanying text.

s2 See Bratton v. City of Detroit, 704 F.2d 878 (6th Cir. 1983), cert. denied, 464 U.S. 1040 (1984). The court distinguished the Police Board's actions from those taken by the Regents in Bakke on the ground that the Police Board had made findings of its own past discrimination, while the Regents had acted only to remedy societal discrimination. The Police Board, the court argued, was competent to remedy its own prior acts. The Regents, conversely, were not competent to remedy amorphous societal discrimination. Id. at 888 
Finally, several courts have hinted at formulations of a more permissive "public body with competence to act" test. They reason that a nonlegislative body with public visibility and an expertise in administering a particular field is not disabled from adopting a race-conscious plan by the absence of an explicit grant of authority or particularized findings. These courts conclude that the visibility and general expertise of the agency provide a sufficient restraint to insure that the affirmative action plan is not impermissibly motivated. ${ }^{83}$ Often this view is left implicit, and the courts simply gloss over the issue of competence. ${ }^{84}$ Consequently, these courts may approve agencies as competent to adopt race-conscious plans without considering the extent of the agency's findings of past discrimination. ${ }^{85}$

\section{Principles of Competence}

This confusion of doctrines within the Supreme Court and among the state and lower federal courts has left affirmative action law in disarray. Justice Powell's notion of "competence" suggests a possible resolution of the confusion: Assuming the constitutionality of remedial affirmative action, courts should focus on ensuring that an institution's asserted remedial motive is legitimate. Thus, a court's central challenge when reviewing an allegedly remedial affirmative action plan is to distinguish between true and false remedial claims. The concept of competence does this by testing the reliability of the government's claim of a past violation of the antidiscrimination laws. If a government body's claim of a past violation is reliable, then a reviewing court can be confident that a legitimate remedial interest actually motivated the race-conscious plan.

In attempting to articulate a theory of competence, the following discussion coincides with much of Justice Powell's approach in Bakke and Fullilove. In particular, this section looks closely at the

n.33.

ss See, e.g., Kromnick v. School Dist., 739 F.2d 894, 906-07 (3d Cir. 1984), cert. denied, 105 S. Ct. 782 (1985); see also O'Neil, supra note 44, at 154-55. This approach is occasionally used as a supplement to the two tests just discussed.

4 See, e.g., Detroit Police Officers Ass'n v. Young, 608 F.2d 671, 694 (6th Cir. 1979), cert. denied, 452 U.S. 938 (1981); Van Aken v. Young, 541 F. Supp. 448, 456 (E.D. Mich. 1982), aff'd, 750 F.2d 43 (6th Cir. 1984). One commentator has gone further, arguing that any public body is competent to adopt an affirmative action plan because remedying societal discrimination and advancing integration are always compelling needs. See Wright, ColorBlind Theories and Color-Conscious Remedies, 47 U. CHI. L. REv. 213, 228-31 (1980).

${ }^{85}$ This is not to say that the courts ignore findings altogether, for they typically scrutinize the extent of findings when they consider the means-end fit, though not in determining competence. 
two requirements Justice Powell seeks to impose on any government body that establishes a remedial plan: authority and findings. These requirements are first examined separately in order to explain how each contributes to the reliability of an institution's claim to be responding to past violations. This section then shows how these two requirements complement one another, and concludes that bodies with greater authority or fact-finding capacity should not be required to make as particularized findings in order to justify their adoption of remedial plans. The final part of this section gives special attention to the example of congressional competence in order to illustrate how these requirements can be applied in the context of a particular government institution.

\section{A. The Authority Requirement}

The first half of the competence inquiry-the institution's authority-asks whether the institution adopting the remedial plan has been given the power to enunciate the government's interests in preventing and eradicating racial discrimination. In one sense, of course, authority is a prerequisite to all government actions, not just those implicating equal protection concerns. A court's general power to review the legality of another branch's action includes the power to determine whether the action is authorized by the Constitution or statute. ${ }^{86}$ On this basis alone, with no help from the fourteenth amendment, a court could strike down the adoption of a plan by a government body lacking the authority to do so. ${ }^{87}$

Within the realm of competence, however, authority takes on an additional role unique to equal protection analysis-authority is an indicator of reliability. If an institution is authorized to advance a particular government interest, it may be more reasonable to presume that the interest it offers to justify its actions actually motivated its adoption of the plan. ${ }^{88}$ Even more to the point, an express

so See Marbury v. Madison, 5 U.S. (1 Cranch) 137 (1803); see also Katzenbach v. Morgan, 384 U.S. 641,649 (1966).

${ }^{87}$ See NAACP v. FPC, 425 U.S. 662 (1976) (agency may impose nondiscrimination obligations on regulatees only insofar as the obligations further goals the agency is authorized to pursue); Steele v. FCC, 770 F.2d 1192, 1196-99 (D.C. Cir. 1985) (female preference in station licensing held to be outside boundaries of commission's delegated authority). In the same manner, findings of past discrimination by a government body not authorized to make them cannot constitute a legitimate statement of government interest; the "government" has not spoken through them at all.

ss See Hampton v. Mow Sun Wong, 426 U.S. 88, 103 (1976) (when "the agency which promulgates the rule has direct responsibility for fostering or protecting [a certain] interest, it may reasonably be presumed that the asserted interest was the actual predicate for the rule."). 
grant of authority indicates that those granting it-the authors of the enabling provision-considered the authorized body to be able to find and remedy discrimination in a reliable manner.

For some institutions, the extent of authority is immense. For example, the authority of a federal court to assert government interests is extremely expansive: article III of the Constitution gives courts broad power to find and remedy constitutional or statutory violations in cases brought before them. ${ }^{89}$ Similarly, according to most of the Justices, section 5 of the fourteenth amendment empowers Congress to find and remedy constitutional violations. ${ }^{90}$ Thus, both courts and Congress have a direct constitutional authorization to find violations of the antidiscrimination laws; this authority legitimates their actions and adds credibility to their conclusion that the government has an interest in correcting the results of such violations.

For other government bodies, the nature of their authority may be both less direct and less specific. If an institution has been delegated explicit remedial power from another government body that is itself constitutionally authorized to institute remedial plans-such as Congress or the President-then the institution's adoption of such a plan might be considered as reliable as an action by the delegating authority. If the terms of the delegation are not explicit, however, or perhaps grant only a general administrative authority without specifically empowering the institution to impose remedial plans, then lack of express or direct authority suggests that the institution's attempt to institute such a plan should be more carefully scrutinized. In Bakke, for example, Justice Powell argued that the Board of Regents was not competent to assess reliably the existence of past illegal discrimination because the California legislature had not specifically delegated to it any such power: "Its broad mission [was] education, not the formulation of any legislative policy or the adjudication of particular claims of illegality."91

s9 Indeed, the same power inheres in all courts-state and federal-by the very nature of the judicial obligation to hear and decide cases, coupled with the commands of the supremacy clause, which binds all judges to enforce the Constitution and laws of the United States as "the supreme law of the land." U.S. ConsT. art. VI.

so See Fullilove, 448 U.S. at 472 (plurality opinion); id. at 508-10 (Powell, J., concurring).

${ }_{91}$ Bakke, 438 U.S. at 309 (Powell, J.). But see id. at 366 n.42 (Brennan, J., concurring) (finding that the Regent's "plenary" authority over the university system was easily broad enough to encompass the authority to remedy past discrimination by adopting race-conscious plans). 


\section{B. The Findings Requirement}

The second part of the inquiry into an institution's competence to adopt remedial affirmative action plans is the requirement that the institution have made some findings of past violations of the antidiscrimination laws. ${ }^{92}$ In a sense, this requirement is also a prerequisite to any remedial government action. No public body is authorized to institute explicit racial classifications without making at least some findings to justify the necessity or propriety of those measures. ${ }^{93}$ If the plan is challenged, the courts must have some basis for testing the strength of the claimed government interest in remedying past discrimination. Without any reviewable findings that the plan serves that objective, the court can only reject the plan as indistinguishable from any other unjustified racial classification..$^{94}$

The record that findings create for judicial review helps a court test the reliability of an institution's asserted remedial motive in two ways. First, findings make it more likely that there has been past discrimination. If the body's findings, as a factual matter, support the conclusion that discrimination occurred, a court need inquire no further into the institution's remedial claims.

But even if findings provide less than conclusive proof of a past violation, they still may be an important indicator of the institution's motive. If the body has gone through the process of uncovering and compiling facts about past discrimination, it is more likely that remedial aims motivated its subsequent use of a raceconscious measure. The process of interpreting facts and weighing evidence will often cause the institution to deliberate and discuss whether discrimination has occurred, so a court can afford to be less suspicious that the body's motive was impermissible. ${ }^{95}$

22 See Fullilove, 448 U.S. at 498 (Powell, J., concurring); Wygant, 106 S. Ct. at 1847-48 (Powell, J.).

A paradigm of what is meant here by "findings" is some sort of reviewable record of facts that support the conclusion that past violations of the antidiscrimination laws have occurred, perhaps indicating both the parties responsible for the violations and those likely to have been affected by them.

os Even the federal courts, which are under an explicit duty to enforce the terms of the Constitution, cannot impose race-conscious remedies unless they are responding to identified instances of past discrimination. See, e.g., Milliken v. Bradley, 418 U.S. 717, 746-47 (1974).

* See McLaughlin v. Florida, 379 U.S. 184, 192 (1964); Korematsu v. United States, 323 U.S. 214, 216 (1944).

os The requirement of deliberation is often used in equal protection cases to help smoke out subtle forms of discrimination. It originated in a proposal that rationality review be made more stringent through the addition of an "articulated purposes" requirement. 
These explanations of why findings must be made also indicate when findings must be made. As Justice O'Connor pointed out in Wygant, ${ }^{96}$ an institution's remedial claim may be reliable even if it did not make its findings at the time it adopted affirmative action; the existence of past discrimination-and thus a remedial interest-might be established conclusively in court when the plan is challenged. But since the ultimate question is whether the institution's motive was remedial at the time it adopted the plan, contemporaneous findings are far more reliable than those made during later litigation. Hence, a court need not test the accuracy of contemporaneous findings with the same vigor it would give to non-contemporaneous findings.

\section{How Detailed Must Findings Be?}

1. The Relation Between Institutional Structure and Findings. Although public institutions must make findings before adopting remedial plans, not all institutions should be required to compile a court-like record before doing so. A body's determinations may be particularly reliable if its fact-finding abilities complement or even improve on those of the courts. Where the nature of the institution gives a court special reason to rely on its factfinding capacities, the court should accept less particularized findings as adequate to justify the adoption of a remedial plan.

Congress is a good example of a body with fact-finding capabilities that complement or improve on those available to the courts. The institutional structure of Congress allows it to gather and assess a broader spectrum of information than is available to the courts. Unlike judges, legislators need not rely solely on the parties close to a dispute to present the facts necessary to its resolution; Congress's information may come from a wide variety of parties and observers. ${ }^{87}$ Such evidence can also be considered with-

This would permit courts to uphold a classification only if the asserted purpose of the legislation was evidenced by the legislative history. See Gunther, supra note 9, at 21; cf. United States R.R. Retirement Bd. v. Fritz, 449 U.S. 166, 182 (1980) (Brennan, J., dissenting) (adopting this approach).

When classifications potentially result from impermissible motivations, the deliberation requirement may be used to determine whether permissible or impermissible motivations lie behind the legislation. See, e.g., Rostker v. Goldberg, 453 U.S. 57, 64 (1981); Califano v. Webster, 430 U.S. 313, 317 (1977); Matthews v. Lucas, 427 U.S. 495, 509-10 (1976).

${ }^{26}$ See Wygant, 106 S. Ct. at 1856-57 (O’Connor, J.).

${ }^{27}$ See Howard, Adjudication Considered as a Process of Conflict Resolution: A Variation on Separation of Powers, 18 J. PUB. L. 339, 350-51 (1969). Courts do have some tools to enhance their information-gathering ability, however, such as expert witnesses and special masters. See Wells \& Grossman, The Concept of Judicial Policy-Making: A Critique, $15 \mathrm{~J}$. 
out the formal limits imposed by judicial rules of evidence or procedure. Congress can consider all evidence that may bear on the issue at hand, including evidence that might confuse a jury or prejudice a defendant. ${ }^{88}$

Congress also has special tools that allow it to consider and interpret information perhaps more effectively than can a court. To begin with, Congress has an advantage in manpower. For violations with complex histories, the collective understanding attainable by legislators and their staffs may far exceed that possible for a single judge. Congress also aggregates experience in addressing a particular problem over time, since its considerations extend beyond the bounds of a single case. ${ }^{9 \theta}$ Also, the committee system allows legislators to develop areas of expertise. ${ }^{100}$

These institutional advantages become even more valuable when they are applied to the kind of facts necessary to establish a violation of the fourteenth amendment. The equal protection clause reaches beyond purposeful discrimination by the state; it also forbids state action which tends to perpetuate the effects of past discrimination by private parties. ${ }^{101}$ This principle was firmly

Pug. L. 286, 305-06 (1966).

" Of course, many evidentiary and procedural rules enhance the accuracy of adjudication, but these benefits are peculiar to the judicial process. The same rules would probably be counterproductive if they were applied to legislative inquiries, which do not seek to maintain impartiality in any strict sense but instead build on the representative nature of the institution to gather a broad range of information. See infra notes 111-15 and accompanying text.

" Justice Powell made this point in Fullilove, noting that Congress relies on "information and expertise that [it] acquires in the consideration and enactment of earlier legislation. After Congress has legislated repeatedly in an area of national concern, its Members gain experience that may reduce the need for fresh hearings." 448 U.S. at 503 (Powell, J., concurring).

100 See Donald Horowitz, The Courts and Social Policy 28-29 (1977).

${ }_{101}$ See City of Rome v. United States, 446 U.S. 156, 176-77 (1980) (noting that Congress may determine that certain voting rights provisions are "appropriate methods of attacking the perpetuation of earlier, purposeful racial discrimination, regardless of whether the practices they prohibited were discriminatory only in effect."); Fiss, Gaston County v. United States: Fruition of the Freezing Principle, 1969 Sur. CT. REv. 379; cf. Jones v. Alfred H. Mayer Co., 392 U.S. 409, 437 (1968) (enforcement clause of antislavery amendment empowered Congress to prohibit discrimination in real estate "whether or not sanctioned by state law"). Indeed, this notion may be a logical result of Katzenbach v. Morgan, 384 U.S. 641 (1966), where the Court's holding implied that Congress's power to enforce the civil war amendments permits it to regulate actions which themselves do not violate the fifteenth amendment. See Cox, Foreword: Constitutional Adjudication and the Promotion of Human Rights, 80 HARv. L. REv. 102-03 (1966). The literacy requirements at issue in Morgan, although not themselves subject to equal protection challenge, could be regulated in order to achieve equal protection in other areas, such as the provision of public services. This holding implies that even though private actions are not subject to direct attack, see Shelley v. Kraemer, 334 U.S. 1 (1948), they may be within the scope of congressional regulation for 
established in the Supreme Court's treatment of voting rights legislation. ${ }^{102}$ For a majority of the Court, Fullilove presented a similar application of that principle: the affirmative action plan they approved was an effort to prevent the government's administration of federal programs from continuing the effects of discriminatory practices by private contractors. ${ }^{103}$

It is easy to see how enforcement of the equal protection clause to its fullest extent depends upon fact-finding techniques and remedial flexibility not commonly seen in courts. For example, even if the alleged discrimination is subject to challenge, a court cannot remedy its lasting effects unless it finds a purposeful government action that perpetuates those effects. ${ }^{104}$ Such a finding

other equal protection purposes.

${ }^{102}$ See City of Rome v. United States, 446 U.S. 156 (1980); Oregon v. Mitchell, 400 U.S. 112 (1970); The Civil Rights Cases, 109 U.S. 3, 23 (1883).

${ }^{103}$ See Fullilove, 448 U.S. at 475-76 (plurality opinion); id. at 520 (Marshall, J., concurring). One could argue that this broader remedial tool might not be available to all governmental bodies. For example, although Justice Powell in Fullilove approved a Congressional plan aimed in part at the effects of private discrimination, his opinion in Wygant implied that a school board has no power to remedy any constitutional violations besides those it has committed itself. Justice Powell (and a majority of the Justices) rejected the argument that a school board could use affirmative action to remedy "societal discrimination." Wygant, 106 S. Ct. at 1847-48 (opinion of Powell, J., joined by Burger, C.J., Rehnquist, and O'Connor, JJ.); id. at 1857(opinion of White, J.). Powell seemed to define "societal discrimination" as any discrimination not practiced by the same public body which has adopted the remedial plan. Id. at 4481 (Powell, J.) (in the past, the Court has allowed raceconscious remedies only for "prior discrimination by the governmental unit involved"); see also id. at 1854 (O'Connor, J.) (" 'societal' discrimination . . . is discrimination not traceable to [the agency's] own actions").

This distinction is sensible, but it should be understood to be a consequence of the differences in authority commonly seen among government bodies. See supra notes 86-91 and accompanying text (discussing the authority requirement). Congress, because of its generalized authority to remedy violations of the fourteenth amendment, and state legislatures, which possess broad police powers, may not be limited to remedying violations of their own making. Local agencies, like school boards, typically possess a much narrower grant of power. In the absence of express delegation, the only remedial authority such bodies may exercise is the power to correct their own transgressions of the antidiscrimination laws. See infra notes 168-72 and accompanying text.

This suggests that the dividing line between "societal discrimination" and institutionspecific discriminatory acts may not be as clear as the Wygant opinions imply. Other remedial discriminatory effects lie between those two extremes, including discrimination practiced by other branches or levels of government, see Civil Rights Cases, 109 U.S. at 23 (Congress can enforce the fourteenth amendment against the states), and government acts which tend to perpetuate the effects of private discrimination, see Fullilove, 448 U.S. at 475-76 (plurality opinion) (fourteenth amendment empowers Congress to reach effects of past private discrimination). These forms of discrimination are much more specific than "societal discrimination," and they may be remedied by authorized government bodies that are not in fact responsible for them.

104 See Washington v. Davis, 426 U.S. 229, 239 (1976); Swann v. Charlotte-Mecklenburg Bd. of Educ., 402 U.S. 1, 22 (1971). Those effects, however, are the only facts that the 
may be unlikely, however, since the perpetuation may be subtle or inadvertent. ${ }^{105}$ Thus, if the courts alone were empowered to find and remedy violations of the antidiscrimination laws, many of the effects of discrimination would remain unreachable even though they are remediable under the fourteenth amendment.

A legislative body like Congress, on the other hand, is in a good position to spot government perpetuation of private discrimination. Indeed, Congress itself would be "responsible" for any perpetuation through federal programs. Congress may also have intimate knowledge of state activities that perpetuate discrimination, given the information it derives from overseeing federal revenuesharing programs and commerce regulation. In contrast, a court depends on the affected parties to bring government perpetuation to light, despite the fact that private parties may not appreciate the effects of the government's actions. In addition, although an equal protection violation is established primarily on the basis of motivations, ${ }^{108}$ its perpetrators may be reluctant to admit their true purposes. ${ }^{107}$ Under these circumstances, Congress's information-gathering capacity, which is both more dispersed and free of procedural formalities, may be more effective than a court's techniques.

Just as a legislature may have superior access to information about the parties responsible for discriminatory effects, so too it will often be in a better position to hear from the parties who may be the most affected. A court might never hear from those injured by discrimination or its continuing effects. The initial victims may have lost their rights to seek a judicial remedy, and of course they could never seek such redress at all if for some reason they could not show a particularized injury. The people with the greatest incentives to seek redress-those who are presently affected-very often were not the targets of the original discrimination. Although these people stand to benefit the most from affirmative action, they may not be in a position to receive judicial relief.

On the other hand, the representative nature of Congress is a great aid in discerning the secondary effects of a violation. ${ }^{108}$ The

affected parties are likely to be in a position to bring to a court's attention.

${ }^{105}$ See Wright, supra note 84, at 223-24; Fiss, supra note 101, at 431-32 (discussing the evidentiary difficulties that confront a court in trying to reconstruct the effects of past discrimination in voting, given a court's "authoritarian, nonrepresentative nature as an institution").

${ }^{108}$ See, e.g., Washington v. Davis, 426 U.S. 229 (1976).

107 See D. HoRowITz, supra note 100, at 48.

${ }^{108}$ Although Congress's institutional structure suggests that it might be better than the 
prospect of re-election induces legislators to be sensitive to the complaints of their constituents, including those who have been hurt by the effects of past discrimination. ${ }^{109}$ As noted above, legislators hear from a larger constituency than could ever be brought to bear in a judicial action. In addition, the more relaxed procedures exercised in Congress allow it greater freedom to measure intensities among this broader array of preferences. ${ }^{110}$

These considerations suggest why the findings requirement should be relaxed when it is applied to Congress, but they do not define the kind of findings a court should require Congress to make. Since Congress has particular advantages in finding past violations of the antidiscrimination laws-advantages that complement rather than simply reflect those possessed by courts-it would be wrong to require it to compile a court-like record before instituting a remedial plan. Instead, Congress need only make some less particularized showing that it has found a past violation. The record it compiles should contain some evidence that Congress attended to this issue and found such a violation in order to justify its adoption of race-conscious remedies.

The major challenge to this approach comes from Justice Stevens. Because he regards findings as a means to establish a public institution's impartiality, he concludes that the findings requirement could not be relaxed at all for Congress: only a court-like adjudication could impartially establish the existence of a violation. ${ }^{111}$ This view should be rejected, as it was by the Court in Ful-

courts at remedying past societal discrimination, see Note, Judicial Deference, supra note 70 , at 1245 n.76 (attributing the Court's deference in Fullilove to Congress's special ability to see "societal discrimination"); see also Fullilove, 448 U.S. at 520 n.4 (Marshall, J., concurring), a majority of the Supreme Court has foreclosed such a justification for affirmative action. Wygant, $106 \mathrm{~S}$. Ct. at 1847-48 (Powell, J., joined by Burger, C.J., Rehnquist and O'Connor, JJ.); id. at 1857 (White, J.). That does not mean, however, that the fourteenth amendment does not reach the effects of private discrimination which government action may perpetuate. See supra note 103.

${ }^{100}$ This is not to say that a legislature may always be relied upon to protect the interests of minorities. See John Ely, Democracy and Distrust ch. 6 (1980) (discussing the judicial role for protecting minority participation in the legislative process).

${ }_{110}$ See D. HoRowrTz, supra note 100, at 44; Komesar, Taking Institutions Seriously: Introduction to a Strategy for Constitutional Analysis, 51 U. CHI. L. REv. 366, 379-80 (1984).

111 See Fullilove, 448 U.S. at 553-54 (Stevens, J., dissenting) (Congress can make remedial racial classifications only if it demonstrates it acted "impartially"); see also id. at 527 (Stewart, J., dissenting) (legislatures cannot make remedial racial classifications because they lack the "dispassionate objectivity" and "flexibility" of a court); Wygant, 106 S. Ct. at 1869-70 (Stevens, J., dissenting) (fairly negotiated and approved collective bargaining agreement including affirmative action provision was procedurally sufficient to protect interests of burdened class). 
lilove. ${ }^{112}$ Obviously, impartiality is required in any proceeding that may result in a sanction affecting the party guilty of the violation; due process guarantees as much. ${ }^{113}$ But an affirmative action plan aimed at remedying the effects of past discrimination is not such a claim: it will be challenged not by the "guilty" parties-the alleged perpetrators of the discrimination-but rather by the members of a class who are burdened by the plan.

To understand why this burden imparts no special procedural rights, it is helpful to separate two distinct aspects of the injury. On the one hand, those burdened by an affirmative action plan are denied a tangible benefit of some sort. Bakke, for example, was denied admission to medical school. This burden, taken separately from equal protection concerns, is no different from the costs that may be imposed on citizens by any act of legislation. Yet legislatures need not compile a court-like record in order to impose such burdens. The representative process is considered completely adequate to protect against arbitrary decisions. ${ }^{114}$

112 See supra note 15.

113 See, e.g., Gibson v. Berryhill, 411 U.S. 564 (1973).

114 This characteristic of congressional fact-finding has also supported deference to Congress's findings in areas outside of equal protection. One such example is the theory of legislative and adjudicative facts in administrative law. See 1 KanNETH DAvis, AdmINISTRATIVE LAw TrBatise $\$ 7.02$ (1958). Under this theory, the degree of due process protection given to individuals affected by administrative actions varies depending on whether the action contested is broad or narrow in its scope. As Justice Holmes stated in Bi-Metallic Investment Co. v. State Bd. of Equalization, 239 U.S. 441 (1915), an action with broad effect-such as a general increase in tax rates-need not be accompanied by an opportunity to be heard. Id. at 445 . But due process may require such an opportunity where the action concerns "[a] relatively small number of persons . . . who [are] exceptionally affected, in each case upon individual grounds." Id. at 446 (distinguishing Londoner v. City of Denver, 210 U.S. 373, 385 (1908)). The former action resembles "legislation," the latter "adjudication."

The two kinds of actions carry different procedural requirements because they seek to uncover different kinds of information. Adjudication depends on facts about the particular activities, business, and properties of the parties. Legislative facts are general facts which bear on questions of policy. Due process imposes less need for hearing the particular parties affected by legislative facts because those individuals are less likely to provide unique information important to an accurate decision. Indeed, for the purposes of due process, the findings of legislatures are assumed to be based upon "adequate lnowledge after full consideration and through members who represent the entire public." Southern Ry. v. Virginia, 290 U.S. 190, 197 (1933).

With regard to affirmative action, determinations about the effects of past discrimination depend more on legislative facts than on adjudicative facts. The class burdened by an affirmative action plan offers no information relevant to the violation or its effects. And since the burdens are distributed on a class-wide rather than an individual basis, the legislature would probably learn little from members of the burdened class.

This account undercuts Justice Stevens' view that those burdened by a remedial plan are entitled to plenary court-like findings by a legislature. Since the parties eventually bur- 
The impetus for a searching inquiry into intent, and thus a findings requirement, comes instead from the separate claim that the affirmative action plan has violated the rights of the burdened class to be free from impermissible racial classifications. The strength of this claim is not necessarily related to the magnitude of the burden imposed. Even a slight burden may violate the fourteenth amendment if imposed in a discriminatory fashion. ${ }^{115} \mathrm{Re}$ gardless of its strength, the equal protection claim can be overcome if the racial classification has a legitimate remedial purpose.

Thus the level of findings that courts should impose on Congress-and on any other public institution-depends on the reliability of that body's findings of past discrimination. The issue is solely one of reliability in finding past violations: members of the burdened class have no particular claim to impartiality as to this aspect of the analysis, since they are not accused of any violation themselves. Once findings have been made that are sufficient to establish the existence of a past violation, any complaints about the burden imposed by the plan are no different from a challenge to any other legislative decision.

In addition to its theoretical soundness, this general approach has precedential support. In other situations, the Supreme Court has advocated deference to initial fact-finders that are especially well positioned to find equal protection violations. This is true of course for any district court's finding that the antidiscrimination laws have been violated. ${ }^{116}$ Likewise, courts have been extremely deferential to school boards which have found that they themselves discriminated in the past. ${ }^{117}$ Just as the findings of fact in these situations are made more reliable by their special access or proximity to the violation, so the findings of Congress are more reliable because of its special ability to take into account the concerns of parties affected by affirmative action.

dened by an affirmative action plan seldom have anything to add to the facts available to the legislature-since they have no special knowledge of particular facts relevant to the existence of a violation-there is little justification for requiring Congress to take special precautions or create a court-like record to address their potential complaints. Instead, the issue of the distribution of burdens imposed by such a plan is simply one of legislative facts.

115 See Personnel Admin. v. Feeney, 442 U.S. 256, 277 (1979) ("Invidious discrimination does not become less so because the discrimination accomplished is of a lesser magnitude."). The extent of due process protection, on the other hand, may well vary with the gravity of the potential injury. See, e.g., Mathews v. Eldridge, 424 U.S. 319 (1976).

${ }^{118}$ Even where such findings lead to the use of racial classifications, a district court's findings of fact about discrimination are subject to reversal only if they are clearly erroneous. See Pullman-Standard v. Swint, 456 U.S. 273 (1982).

117 See McDaniel v. Barresi, 402 U.S. 39 (1971). 
2. The Relationship Between Authority and Findings. A body's institutional character is not the only measure of reliability affecting the level of findings that should be required. The nature and scope of an institution's authority may also provide a reason to defer to the assertion that a remedial purpose motivates its adoption of a race-conscious plan. This suggests that where the grant of authority to a government body is direct or explicit, a court can relax the findings requirement accordingly. ${ }^{118}$ Yet this relation can never go so far as to permit an institution to dispense with the findings requirement altogether. Even an institution that held a very strong or "absolute" grant of power to take such measures might do so without adequate justification-hence the need for at least some findings in every case. ${ }^{110}$

This relation between authority and findings finds considerable support in the congressional example. In Fullilove, the Court noted Congress's broad authority to find and remedy violations of the antidiscrimination laws under both the commerce clause and the enforcement clause of the fourteenth amendment. ${ }^{120}$ And the Court required little in the way of congressional findings, suggesting that if the Constitution directly empowers Congress to identify and correct such violations, it allows Congress to exercise that power through the same procedures that Congress uses for any other decision. As Justice Powell wrote, "Congress is not an adjudicatory body .... . [It] is not expected to act as though it were duty bound to find facts and make conclusions of law. The creation of national rules for the governance of our society simply does not entail the same concept of recordkeeping that is appropriate to a judicial or administrative proceeding."121 Chief Justice

118 Justice Powell suggested this conclusion in his concurrence in Fullilove: "The degree of specificity required in the findings of discrimination and the breadth of discretion in the choice of remedies may vary with the nature and authority of a government body." 448 U.S. at 515 n.14; see also Ohio Contractors Ass'n v. Keip, 713 F.2d 167, 170-71 (6th Cir. 1983); Michigan Road Builders Ass'n v. Milliken, 571 F. Supp. 173, 177-78 (E.D. Mich. 1983).

11 See Bakke, 438 U.S. at 366 (Brennan, J., concurring) (recognizing the need for some "reason to believe" the race-conscious action serves a remedial purpose).

120 See Fullilove, 448 U.S. at $472-75$ (plurality opinion); id. at 499-500 (Powell, J., concurring).

121 Id. at 502 (Powell, J., concurring). Justice Powell was emphatic on this point; a rigorously enforced findings requirement, he said, "would mark an unprecedented imposition of adjudicatory procedures on a coordinate branch of Government." Id. at 503. In part, this approach reflects a view of Congress's capacity to compile court-like findings. A legislature may not be able to make detailed findings because much of the knowledge on which its members rely never appears in committee reports, hearings, or debates. Much information comes instead from the daily exposures uniquely available to a "people's representative." 
Burger's plurality opinion also stated that the Court owed special deference to the conclusions of Congress based on Congress's elevated station in the constitutional scheme. ${ }^{122}$

Deference to congressional findings on the basis of Congress's special authority is particularly consistent with the Court's broader understanding of section 5 of the fourteenth amendment. In Katzenbach $v$. Morgan, ${ }^{123}$ the Court held that section 5 gives Congress a measure of authority to enforce the fourteenth amendment that is comparable to Congress's power to regulate interstate commerce under the necessary and proper clause. Within the sphere of commerce regulation, the Court permits Congress to take any reasonable means to implement its desired ends, so long as the ends are permissible. ${ }^{124}$ Morgan itself applied commerce-like deference to a statute aimed at enforcing the equal protection of the laws by altering a state's voting procedures. Since a remedial affirmative action plan also falls within the legitimate objectives of section 5 , Morgan's deference to Congress's choice of means to implement a remedy might also justify relaxation of the findings requirement. ${ }^{125}$

Indeed, much of the reasoning in Morgan directly supports deference to congressional findings. Although the Court found it necessary to decide whether the end sought to be achieved by the legislation-greater equality in the provision of public services-was within the legitimate goals of equal protection, ${ }^{126}$ the Court deferred to Congress's finding that the end itself was real-that there might have been discrimination in public services. ${ }^{127}$ And without stringent review, the Court also allowed Congress to balance the competing constitutional interests implicated

\footnotetext{
See Cox, supra note 101, at 105.

122 Fullilove, 448 U.S. at $473,480$.

${ }^{123} 384$ U.S. 641 (1966).

124 See McCulloch v. Maryland, 17 U.S. (4 Wheat.) 316 (1819).

125 The Court's holding in Oregon v. Mitchell, 400 U.S. 112 (1970), which refused to defer to Congress's choice of means in altering state voting age requirements, might seem to contradict this understanding. But Mitchell did not undermine Morgan with regard to congressional power to enforce the fourteenth amendment's prohibitions against racial discrimination. Justice Black's decisive concurrence in Mitchell distinguished Morgan on that very basis. See id. at 129.
}

128 Morgan, 384 U.S. at 649-50.

${ }^{127}$ See id. at 652 (hypothesizing several findings of fact Congress might have made, any of which would have sufficed). Morgan's deference to congressional fact-finding about the existence of a permissible objective is underscored by the explicit disagreement between majority and dissent on the adequacy of the legislative record supporting the challenged law. Compare id. at 653-58 (citing congressional debates) with id. at 669 (Harlan, J., dissenting) (" $[t]$ here is simply no legislative record supporting such hypothesized discrimination" in public services). 
by the legislation. Extensive findings were not required to prove that Congress's constitutionally recognized enforcement interest outweighed the constitutionally reserved powers of the states to regulate voting. ${ }^{128}$

This complementary relationship between authority and the levels of findings required also builds on familiar principles of judicial power. The findings requirement facilitates judicial review of the factual inferences that underlie a government body's decision; lower courts and administrative agencies compile extensive records for this reason. ${ }^{129}$ But when a public institution is expressly granted authority to identify or define government interests, a court has proportionally less power of review or justification for requiring extensive findings. ${ }^{130}$

An explicit grant of implementation power, such as the necessary and proper clause or section 5 , is just such a special grant of authority; it inevitably gives Congress much room for discretion..$^{131}$ With regard to implementing legislation, this discretion weakens the traditional presumption that only the judiciary may interpret the Constitution conclusively. If Congress can interpret the fourteenth amendment, it has some power to define which conduct violates the amendment. ${ }^{132}$ And if it can define violations, surely it

${ }^{122}$ See id. at 653 (Congress is allowed to "assess and weigh the various conflicting considerations"); Cox, supra note 101, at 104.

${ }_{129}$ See, e.g., Mobil Oil Corp. v. FPC, 483 F.2d 1238, 1257-63 (D.C. Cir. 1973) (statutory provision giving courts power to review agency decision for "substantial evidence" implies that agency must compile record to facilitate review).

130 Deference to another institution's ability to identify interests is nothing new in the area of equal protection. The Court's first case applying strict scrutiny, Korematsu v. United States, 323 U.S. 214 (1944), accepted the military's conclusion that internment of the Japanese was necessary to the war effort, and thus supplied a compelling government interest. Id. at 219-20. The decision may be understood as expressing the Court's doubts about its own competence to test the military's findings. See Komesar, supra note 110, at 390-91; see also Rostker v. Goldberg, 453 U.S. 57 (1981) (court must accept Congress's judgment that military needs justify registering only men for potential conscription).

131 See Morgan, 384 U.S. at 650-51.

122 See id. at 648-49 (holding that Congress may prohibit action under the fourteenth amendment without a judicial finding that the action is unconstitutional).

Not only were the theoretical bases for deference in Morgan and Fullilove nearly identical, but the cases confronted congressional findings of the same character. To justify the remedial plan in Fullilove, Congress needed to confirm the existence of past discrimination and its harmful effects. This finding paralleled Congress's conclusion in Morgan that voting standards resulted in unequal public services. See 384 U.S. at 652 . Once a violation was established in Fullilove, Congress had to balance the magnitude of this interest against the rights of the burdened class to be free from racial classifications. Likewise, the Morgan Court deferred to Congress's balance of state and individual interests. See id. at 653. These similarities also reconcile the Court's deference in Morgan with that of the Fullilove plurality. 
can identify them when they occur.

The difficulty with an approach that aligns the rigor of the findings requirement with the strength of the authorization lies in constructing the balance between the authorization and the need for findings. In some instances, the strength of the authorization may be unclear. ${ }^{133}$ Also, the congressional example offers little obvious guidance about the competence of other government bodies, whose authority typically rests on a weaker foundation, such as a mere statutory grant of authority without particular terms from another government body.

\section{Applying the Principles of Competence to Public INSTITUTIONS}

The previous section's analysis shows that "competence" is a complex blend of factors that run much deeper than the labels "authority" and "findings" first suggest. Yet certain basic principles of competence have been identified. Authority is a critical feature not only as a primary indicator of an institution's reliability, but also because it may constrain the scope of judicial scrutiny of an institution's actions. In addition, the strength of authority affects the scope of the necessary findings. The level of findings required also depends on the practical aspects of an institution's structure and procedures that make its determinations more or less reliable. Thus the deference accorded to an institution's findings depends also on how much need exists for close judicial oversight of its particular decisionmaking process.

Although this basic framework provides a fuller explanation of "competence" than is given in the cases, it remains vague until it is applied to the various government institutions that may promulgate remedial affirmative action plans. This section applies these principles to state and local legislative bodies and to agencies in order to get an idea of which public institutions are competent to

1ss See Tushnet, Legal Realism, Structural Review \& Prophecy, 8 U. DAYTON L. Rev. $809,816,823$ (1983) (discussing the difficulties of determining an agency's mission). This may be a problem even where the grant of authority is explicit and very powerful, if the grant is at all ambiguous. For example, even section 5 of the fourteenth amendment, by its terms, is susceptible to more than one interpretation. It could mean that Congress has the authority to find and remedy violations of the antidiscrimination laws; hence federal courts would owe deference to Congress's conclusion that a violation exists. Or it could be taken to mean that Congress has only the power to impose a remedy for what has already been properly identified as as violation of the law, leaving a court to review only the method by which Congress discerns the violation in the first place. 
adopt remedial plans. ${ }^{134}$

\section{A. State and Local Legislatures}

1. State Legislatures. The Supreme Court has never tested the competence of state legislatures to adopt race-conscious remedial plans. Lower courts have done so using an analysis nearly identical to the Court's approach in Fullilove. And their analysis has led to the same kind of deference for the findings of state legislatures which the Supreme Court gave to the national legislature. ${ }^{135}$ According to the principles developed in this comment, this is the correct approach.

Congress's strong authority to find past violations of the antidiscrimination laws flows primarily from its power to enforce the fourteenth amendment. State legislatures hold their authority as part of a much more general entitlement: the police power inherent in every state government to "protect the health, safety and morals of the community." ${ }^{136}$ In these areas, the state's power extends to all powers not explicitly reserved to the federal government or withheld from the states. ${ }^{197}$ Arguably, then, the police power might permit a state legislature to enunciate state interests in identifying and remedying illegal discrimination and its effects.

On the other hand, one could argue that the power to tackle discrimination falls outside the realm of a state's police power. If Congress needed the strong language of section 5 of the fourteenth amendment to obtain the authority to implement remedial plans, ${ }^{138}$ why should a state's vague police power be thought to include such power without an explicit enforcement provision like section $5 ?^{139}$

134 As noted previously, if the competence of a public institution is established, that merely affirms the government's legitimate interest in adopting the remedial plan. It does not establish the ultimate validity of the plan; the plan must also be narrowly tailored to remedy the past discrimination that was identified. This remaining issue of the "means-end fit" is discussed briefly infra note 174 .

${ }^{235}$ See, e.g., Ohio Contractors Ass'n v. Keip, 713 F.2d 167 (6th Cir. 1983); Michigan Road Builders Ass'n v. Milliken, 571 F. Supp. 173 (E.D. Mich. 1983).

${ }^{138}$ Sax, Takings and the Police Power, 74 YALE L.J. 36, 36 n.6 (1964); see also ERNST FreUnd, THE Police Power 3 (1904) (the police power "aims directly to secure and promote the public welfare"); 6 Eugene McQuiLin, Municipal Corporations $\S 24.07$ (3d ed. rev. 1980) ("the police power belongs exclusively to sovereignty and inheres in the state").

137 See E. FreUnd, supra note 136, §§ 62-63.

228 See supra notes $90,120$.

150 See Central Alabama Paving, Inc. v. James, 499 F. Supp. 629, 634 (M.D. Ala. 1980) (only Congress may enact an affirmative action plan, though it may delegate that power if it explicitly "command[s] such disparate treatment"); Choper, The Constitutionality of Affirmative Action: Views from the Supreme Court, 70 KY. L.J. 1, 12-13 (1981-82) (outlining 
The answer to this argument lies in careful analysis of the nature of a state's police power. Most important, a state's power to enact legislation relating to the health and morals of its citizens clearly encompasses the subject of racial discrimination, a critical issue in modern American society. Yet, in the absence of section 5, the enumerated federal powers might reach it only indirectly, perhaps through congressional control of interstate commerce. ${ }^{140}$ This would explain why an affirmative grant of power might be necessary for federal action, but not for state action. ${ }^{141}$ And in any event, the Supreme Court has recognized state power to enforce the equal protection clause, albeit outside the sphere of affirmative action, by ruling that "there is no doubt that legislation which prohibits discrimination on the basis of race ... is within the police power of the states."142

On this basis, some courts have considered the police power a source of authority sufficient to eliminate the need for a state legislature to make particularized findings of past violations. ${ }^{143}$ In part, this deference expresses a belief that state legislatures would be unable to compile meaningful findings. Like Congress, their decisionmaking depends on methods of information-gathering that do not lend themselves to the compilation of written records. ${ }^{144}$ In light of the state's extensive police power, and since more stringent review might create practical problems, courts have found state legislatures competent to identify violations without requiring particularized findings.

For the courts to require no findings, however, would provide inadequate assurance that the remedial motive asserted by the legislative was in fact legitimate. Nonetheless, the principles of competence indicate that the findings requirement can be relaxed substantially for state legislatures. State legislatures share many of the

the argument). In fact, the argument for exclusive congressional power is strengthened by comparing the enforcement clause of the fourteenth amendment, which provides only for congressional enforcement, to the enforcement clause of the eighteenth amendment, which explicitly delegated such power to the states and Congress concurrently. See U.S. ConST. amend. XVIII, \& 2 (repealed 1933).

160 Congress's commerce power may have provided an additional foundation for the preference plan approved in Fullilove. See supra note 120.

${ }^{141}$ See Ohio Contractors Ass'n v. Keip, 713 F.2d 167, 172 (6th Cir. 1983) (outlining but rejecting the argument that only Congress may enact affirmative action plans).

142 District of Columbia v. John R. Thompson Co., 346 U.S. 100, 109 (1953).

14 See, e.g., Keip, 713 F.2d at 171-72.

24 In addition, written records are often not kept in state proceedings. See, e.g., May v. Cooperman, 572 F. Supp. 1561, 1564 (D.N.J. 1983) (no records for New Jersey legislature), aff'd, 780 F.2d 240 (3d Cir. 1985). 
violation-finding capabilities possessed by Congress. ${ }^{145}$ The representative nature of the relationship between legislators and constituents facilitates communication of information about a broader class of perpetrators and victims of discrimination than might have access to the courts. State legislatures can find facts informally and aggregate information over long periods to develop a sophisticated understanding of discriminatory motivations. Indeed, these capabilities might even be enhanced at the state level, where closer proximity to problems allows a sharper focus. Thus, courts should require only minimal findings as a prerequisite to the adoption of remedial plans by state legislatures. Courts should have some proof that the adopted plan was intended to serve a remedial interest, and that the legislature engaged in some discussion about the past violations, either at the time of adoption or at some point in the recent past. ${ }^{148}$

2. Local Representative Bodies. The Supreme Court also has not spoken directly about the competence of local bodies with elected officials, such as county legislatures and city councils. The lower courts have usually considered such bodies to be analogous to state legislatures. ${ }^{147}$ Yet the two kinds of institutions differ in two important respects.

${ }^{315}$ See supra notes 97-110 and accompanying text (describing Congress's fact-finding characteristics).

${ }^{148}$ Keip is an excellent example of the approach suggested here. In that case, a remedial plan was upheld even though the state legislature made no specific findings of past discrimination. See 713 F.2d at 169-71. The court rested its conclusion primarily on prior studies made by committees of the legislature as evidence of the discrimination problem that the legislature sought to address. See id. at 171.

Given that some state legislatures keep few or no records of their proceedings, however, even the minimal findings requirement suggested by Justice Powell in Fullilove might call for modified procedures during the consideration of affirmative action legislation. For example, witnesses might help to to reconstruct the legislative process by recounting the findings of discrimination underlying the legislature's adoption of a preference. This technique has been used in other contexts to determine statutory purpose. See, e.g., May v. Cooperman, 572 F. Supp. 1561 (D.N.J. 1983), aff'd, 780 F.2d 240 (3d Cir. 1985).

${ }^{167}$ On county legislatures, see South Fla. Chapter of the Ass'd Gen. Contractors of Am. v. Metropolitan Dade County, 723 F.2d 846 (11th Cir. 1984), cert. denied, 105 S. Ct. 220 (1984); Southwest Wash. Chapter of the Nat'l Elec. Contractors Ass'n v. Pierce County, 100 Wash. 2d 109, 122, 667 P.2d 1092, 1099 (1983) (en banc). On city councils, see Local 35, IBEW v. City of Hartford, 625 F.2d 416 (2d Cir. 1980), cert. denied, 453 U.S. 913 (1981); Germann v. Kipp, 429 F. Supp. 1323, (W.D. Mo. 1977), vacated on other grounds, 572 F.2d 1258 (8th Cir. 1978); Hutchinson Human Relations Comm'n v. Midland Credit Mgmt., Inc., 213 Kan. 308, 578 P.2d 158 (1973) (city and its human relations commission both found competent); Lindsay v. City of Seattle, 548 P.2d 320 (Wash. 1976). But see Arrington v. Associated Gen. Contractors of Am., 403 So. $2 \mathrm{~d} 893$ (Ala. 1981). See generally Note, Race as Employment Qualification to Meet Police Operational Needs, 54 N.Y.U. L. REv. 413, 427 (1979) (discussing city council competence in a nonremedial context). 
First, the authority of local bodies may be less direct or narrower in scope than that of the state legislatures. Local legislatures, such as city councils, operate on the basis of police power delegated from the state. This delegation may be accomplished through a home rule provision in the local body's charter or other organic legislation. ${ }^{148}$ State law generally governs on whether home rule provisions should be construed narrowly or broadly. ${ }^{149}$ If the power to address racial discrimination is not explicitly reserved to the local body, these rules of state law will determine whether this power is included in the more general grant.

Second, although local elective bodies often possess the considerable advantages in information-gathering that derive from their representativeness and institutional structure, their fact-finding capabilities may be inferior to those of state legislatures. Local bodies often represent a smaller and less diverse constituency. They may operate according to less formal procedures, and may in particular lack the more elaborate internal checks and delays that foster expertise and necessitate a more extensive focus on problems in larger legislative bodies. ${ }^{130}$ And although local bodies are even closer to the problems they address than are the state legislatures, their proximity may make them more prone to respond to majority pressures, which could interfere with their ability to gather and assess information. ${ }^{161}$

Therefore, although local representative bodies may to some extent share the state legislature's police power authority and its superior fact-finding capabilities, a more stringent findings requirement is appropriate for many local bodies. A court might require, for example, more specific identification of those who discriminated and those who were discriminated against before it will approve the adoption of a remedial plan.

148 See Osborne Reynolds, Local Government Law § 49 (1982).

149 See id. at \$§ 50-52; see also Southwest Wash. Chapter of the Nat'l Elec. Contractors Ass'n v. Pierce County, 100 Wash. 2d 109, 123, 667 P.2d 1092, 1100 (1983) (en banc).

${ }^{130}$ Examples of these internal checks in many larger legislative bodies are bicameralism, committee systems, and requirements for multiple readings of proposed legislation in each chamber that considers it.

131 See The Federalist No. 9 (A. Hamilton) (suggesting that factions may more easily dominate smaller, local legislative bodies); id. No. 10 (J. Madison) (same). One example of this problem in the equal protection context is the issue of affirmative action undertaken by a "black majority." Because a race-conscious plan adopted by a minority-dominated local legislature may not have received the same level of self-interested scrutiny given a similar plan adopted by a white majority, there may be some reason for a court to examine more closely the asserted remedial interest behind the plan. However, as the existence of a black majority is still relatively unusual in this country, the potential problem would not call for across-the-board heightened scrutiny of remedial interests asserted by local legislatures. 


\section{B. Administrative Agencies}

Courts have rightly examined the actions of agencies more intensely than those of representative bodies, looking closely at agency authority as well as agency findings. To understand the case law and its congruence with the approach to competence proposed here, it is helpful to separate three different ways in which administrative agencies are involved in affirmative action. They can implement a plan developed in detail by Congress or a state legislature; they can develop and implement their own plan with explicit legislative authorization; or they can develop and implement their own plan in the absence of explicit authorization.

Courts rarely question the competence of agencies acting merely to implement plans developed by the legislature. ${ }^{152}$ At issue in such plans is Congress's competence, not that of the agency; Congress effectively defined the government's interests when it authorized those specific measures. At the federal level, this has led courts to approve hiring preferences in consent decrees negotiated by the Equal Employment Opportunity Commission under Title VII, ${ }^{163}$ and to allow the Attorney General to invalidate state literacy tests pursuant to specific provisions of the Voting Rights Act. ${ }^{184}$ For both of these administrative actions, Congress had issued specific guidelines for the agency's implementation. ${ }^{155}$

When agencies both develop and implement a plan with explicit authorization, however, courts have examined their competence more carefully. ${ }^{158}$ On the first consideration-whether the

182 See Bakke, 438 U.S. at 302 n.41 (Powell, J., concurring) (congressionally authorized administrative actions are beyond challenge where there has been "detailed legislative consideration of the various indicia of previous constitutional or statutory violations").

1ss See EEOC v. American Tel. \& Tel. Co., 556 F.2d 167 (3d Cir. 1977), cert. denied, 438 U.S. 915 (1978); EEOC v. Contour Chair Lounge Co., 457 F. Supp. 393 (E.D. Mo. 1978).

1s4 See South Carolina v. Katzenbach, 383 U.S. 301 (1966).

185 For example, the legislative history of Title VII included detailed reports of the severity of discrimination in the United States. See H.R. REP. No. 914, 88th Cong., 2d Sess. 26 (1963). Congress also gave the agencies the criteria for enforcement. The Voting Rights Act only became applicable to a particular state if the Director of the Census found that less than $50 \%$ of the residents had voted and the Attorney General found that a "test or device" abridged the right to vote. 42 U.S.C. $\S 1973 b(a)-(b)(1982)$.

158 The best example of this kind of agency action concerned the implementation of Executive Order 11,246. The executive order explicitly delegated the President's procurement power to the Labor Department for the purpose of "implement[ing] affirmative action" in government contracting. Nearly all the courts that have heard challenges to the Labor Department's implementation have approved it. See Larsen, Race Consciousness in Employment after Bakke, 14 HARv. C.R.-C.L. L. REv. 215, 237 n.110 (1979) (listing cases). Only a few of these cases addressed the issue of the Department's competence to institute the plan. See, e.g., Rossetti Contracting Co. v. Brennan, 508 F.2d 1039, 1045 n.18 (7th Cir. 
authority delegated to the agency includes the power to adopt race conscious remedial plans-courts have been very permissive. They have practically assumed such authority to be established, and have often found it strong enough to lessen the need for agency findings. ${ }^{157}$ The application of competence principles suggests that this approach is too lenient.

First, the scope of the agency's delegated authority should be examined closely in order to discern whether the delegating body itself has the authority to adopt remedial plans, and whether that authority was expressly or implicitly included in the delegation. Courts should also look closely at the agency's exercise of the power it has received, to ensure that it fulfilled any conditions imposed by the delegating body. ${ }^{158}$

Once the agency's authority to adopt remedial plans is established, the question becomes one of what level of findings they must make in support of the claim of past violations of the antidiscrimination laws. Here it is helpful to compare the nature of an agency's delegated power with Congress's direct power under section 5 of the fourteenth amendment. Both sources of power indicate reliability to some extent-the legislature seems to trust the agency just as the drafters of section 5 trusted Congress. But unlike direct section 5 authority, delegated power implies no limitation on a court's reviewing power which would counsel against the strict imposition of a findings requirement. ${ }^{159}$ There is less reason to defer to the agency because, unlike Congress, the agency does not have direct or coequal authority to define constitutional violations. This difference between congressional and direct legislative authority suggests that more particularized findings should be re-

1975); Northeast Constr. Co. v. Romney, 485 F.2d 752, 760-61 (D.C. Cir. 1973).

${ }_{187}$ See, e.g., United States v. New Orleans Pub. Serv., Inc., 553 F.2d 459, 467 n.8 (5th

Cir. 1977) ("only a loose relationship between the noneconomic objective, i.e., regulating employment discrimination, and the procurement function" of the agency need exist).

${ }_{158}$ See supra notes 86-91 and accompanying text. Of course, as the discussion revealed earlier, this basic inquiry into authority is not unique to equal protection analysis.

${ }_{109}$ See supra notes 129-32 and accompanying text (discussing Congress's authority to define violations of the equal protection clause and how this power affects judicial review). Indeed, the delegation of power to agencies is sometimes thought to be justifiable because judicial review is available to contain it. In INS v. Chadha, 462 U.S. 919 (1983), the Court invalidated unicameral legislative oversight of agency action, noting that it amounted to "lawmaking" without compliance with normal lawmaking procedures. The Court distinguished agency action, saying it was not "lawmaking," precisely because such action is "always subject to check by the terms of the legislation that authorized it," and thus is subject to judicial review. Id. at $953 \mathrm{n} .16$. The same might also be said in the state context, where courts would have less reason to defer to a state agency than to the legislature, which wields direct authority under the state's police powers. 
quired before agencies can adopt remedial plans.

This conclusion is also supported by the institutional structure of most administrative agencies. In particular, most agencies lack one aspect that is critical to Congress's reliability: representativeness. Because of this there is less assurance that an agency's claim of a prior violation is informed by broader contacts with the perpetrators or those they have affected. ${ }^{160}$ At the same time, however, agencies do obey a set of procedural rules that are designed to enhance impartiality, and thus may indicate reliability. ${ }^{101}$ In some instances, these rules graft court-like procedures onto agency action, and thus might impart to agencies some features of the competence found in federal courts. ${ }^{162}$ But impartiality is only one indicator of reliability. It says nothing about the sufficiency of the information which underlies the agency's declaration. ${ }^{163} \mathrm{~A}$ requirement of more particularized findings, on the other hand, would address that aspect of reliability directly.

In light of this analysis of agency authority and institutional structure, it would be appropriate for a court to rule that an agency may be given discretionary power to specify and remedy past violations of the antidiscrimination laws only if it does so in a manner that permits meaningful judicial review-in other words, only if it compiles more particularized findings. Such findings could include specific identification of those who discriminated or were discriminated against, and might include detailed statistical

180 Whereas courts need not review the distribution of burdens by a competently adopted legislative plan when testing the government's interest, see supra text accompanying notes 114-15, they should review this aspect of a plan developed through agency action that is less representative. This approach may explain the difference between Justice Powell's deferential treatment of a congressional plan in Fullilove, see supra text accompanying notes $47-48$, and his rigorous attention to the distribution of burdens in a school board's plan in Wygant, $106 \mathrm{~S}$. Ct. at 1849-52.

${ }^{201}$ Federal agency action is regulated by the Administrative Procedure Act (APA), 5 U.S.C. $\$ \S 551-7521$ (1982). States often have open hearing laws to the same effect. See $1 \mathrm{~K}$. DAvis, supra note 114, § 6:04.

${ }^{162}$ This is largely the effect of the APA's formal rulemaking procedures. See 5 U.S.C. $\S 557$ (1982) (setting forth formal rulemaking procedures). When an agency's affirmative action plan produces a court-like record, a court probably need not even confront the findings issue-the record provides sufficient findings in any event.

${ }^{163}$ See supra notes 111-15 and accompanying text (discussing the role of impartiality in assessing competence). Of course, if the institution were representative, as may be the case with school boards, then this is an additional reason for relaxing the findings requirement. Similarly, some police boards have a degree of representative accountability through mayoral supervision. Although it is unclear whether this fact should carry any weight, some courts have thought it important in establishing competence. See Baker, 483 F. Supp. at 993. 


\section{information..$^{164}$}

Finally, if an agency attempts to develop and implement a remedial plan without an explicit legislative directive, the range of competent agency action is very limited. Thus, the position suggested in some lower courts that a nonrepresentative body may adopt a remedial plan if it has public visibility and an expertise in administering a particular field, ${ }^{165}$ must be rejected as too broad. Neither the unpredictable public exposure of a government body nor its general experience in an area can authorize it to act where no specific grant of authority can be found. ${ }^{166}$ In short, at some point a lack of specific authority indicates lack of any authority, regardless of the particularity of findings made. ${ }^{167}$

Nevertheless, lower courts have widely approved one exception to this last category of administrative action: remedial plans adopted by state police and school boards without legislative authorization, where the plans are intended to alleviate the effects of their own past discrimination. ${ }^{168}$ The adoption of these plans was

104 See, e.g., International Bhd. of Teamsters v. United States, 431 U.S. 324,337 n.17, 339 n.20 (1977) (detailing city-specific racial disparities in the freight-driving trade); Contractors Ass'n v. Secretary of Labor, 442 F.2d 159, 163 (3d Cir. 1971) (citing executive finding of disparaties among tradesmen in contracting). This is in contrast to the more relaxed findings that should be required of state legislatures, see supra note 146 and accompanying text, and of local representative bodies, see supra text following note 151.

${ }^{165}$ See the cases discussed supra notes 82-85 and accompanying text.

${ }^{168}$ For Justice Powell, Bakke was just such a case; the Regents failed to show even a minimal level of specific authorization to adopt a remedial affirmative action plan. See Bakke, 438 U.S. at 309 (Powell, J.).

${ }^{367}$ See NAACP v. FPC, 425 U.S. 662 (1976) (agency may impose nondiscrimination obligations on regulatees only insofar as the obligations furthered the intended purposes of the agency); Steele v. FCC, 770 F.2d 1192 (D.C. Cir. 1985) (female preference in station licensing was outside the boundaries of the commission's delegated authority). One could argue, however, that these cases simply stand for the proposition that agency action may not exceed its statutory authority. If the challenged plans had been more closely tied to the agencies' purposes, they might not have been so easily invalidated. Rather, under the competence principles suggested here, a court could have upheld such plans if quite detailed and comprehensive findings had been made. This result would extend Justice Powell's notion of competence, as it would suggest that the Regents in Bakke could have adopted a remedial plan if they had made sufficient findings. Powell rejected this argument. Bakke, 458 U.S. at 309.

168 The primary cases in this area involved an affirmative action plan promulgated by the Detroit Police Board. See Baker v. City of Detroit, 483 F. Supp. 930 (E.D. Mich. 1979), aff'd sub. nom. Bratton v. Detroit, 704 F.2d 878 (6th Cir.), modified, 712 F.2d 222 (1983), cert. denied, 464 U.S. 1040 (1984); see also Detroit Police Officers' Ass'n v. Young, 608 F.2d 671, 694 (6th Cir. 1979), cert. denied, 452 U.S. 938 (1981); NAACP v. Detroit Police Officers' Ass'n, 591 F. Supp. 1194 (E.D. Mich. 1984). Several other cases presented the same issues. E.g., Talbert v. City of Richmond, 648 F.2d 925 (4th Cir. 1981); Van Aken v. Young, 541 F. Supp. 448 (E.D. Mich. 1982).

The Detroit plan had both remedial and nonremedial justifications. Hiring ratios for 
further strengthened by extensive findings. ${ }^{169}$ But if findings can make such unauthorized bodies competent, it might seem that any state body could implement an affirmative action plan in order to remedy the effects of its own violations of the antidiscrimination laws.

The principles of competence developed here support this conclusion. On the authority side, the power of an agency to attack its own violations does not lack for explicit grounding. Although there may be no special grant of authority from some other institution, the authority of any government body to remedy the effects of its own violations comes from the fourteenth amendment itself. The Supreme Court established this point in McDaniel v. Baressi, ${ }^{170}$ where it approved a busing program adopted voluntarily by a school board. In justifying the board's action, the Court stated that the school board had an "affirmative duty" to undo the effects of any violation it had committed in the past. ${ }^{171}$ Thus, a court's authority was not needed for an agency's remedial affirmative action plan; by compelling such action, the fourteenth amendment necessarily authorized it. ${ }^{172}$

This does not mean, however, that an agency is free to use racial preferences to correct its own violations without making any findings. For an agency using its $M c D a n i e l$ power, the existence of a past violation is itself a prerequisite of the agency's remedial authority. Hence, although a self-incriminating admission will often be reliable, ${ }^{173}$ a requirement of particularized findings will help the

blacks were intended both to compensate for a history of discrimination within the police force and to reduce tensions between the police and black citizens. See Baker, 483 F. Supp. at 980,995 . Although the nonremedial aspect does not bear on this comment, see supra note 2, it may well have been an important part of the courts' approval of the Detroit plan.

138 See Young, 608 F.2d at 694; Baker, 483 F. Supp. at 993.

170402 U.S. 39 (1971).

${ }^{171}$ Id. at 41. For this proposition the Court cited Green v. County School Bd., 391 U.S. 430, 437-38 (1968), a case in which the Court conferred broad authority on federal courts to implement remedial busing programs. Apparently, $\mathrm{McDaniel}$ stands for the proposition that this authority inheres in any school district guilty of past discrimination, and a school board need not wait for a court decree in order to exercise its authority.

${ }^{172}$ This authority, however, carries an important caveat. The authority given to a government body under $M c D a n i e l$ is limited to remedies for the effects of discrimination by that body. Without some other source of authority, a body cannot order remedies for the violations of private individuals or other government bodies. Courts should enforce this limitation when they examine the "means-end fit" as the last step in their scrutiny of such plans. For a brief discussion of this problem, see infra note 174 .

${ }^{173}$ As Justice O'Connor pointed out in Wygant, such admissions may increase the institution's exposure to civil rights liability, and reduce voluntary compliance with the antidiscrimination laws. See Wygant, 106 S. Ct. at 1855-56 (O'Connor, J.). But see id. at 1849 n.5 (Powell, J.) (school board's post hoc concession of past discriminatory practices is not 
court to conclusively establish the actor's remedial authority.

\section{Conclusion}

The affirmative action controversy raises a difficult issue: when the need to remedy racial discrimination justifies the use of racial preferences. Yet the traditional approach to racial classifications often seems unable to capture the purposes likely to motivate the use of affirmative action. This comment has argued that when the avowed purpose of a race-conscious plan is the remedying of past violations of the antidiscrimination laws, the best way to ensure that the remedial motives behind the plan are legitimate is to concentrate on the character of the institution implementing it. The central question is whether the institution is competent to adopt such a plan. Competence, in turn, is indicated by two factors that show the reliability of an institution's allegation that past violations have occurred: authority and findings. When both of these factors are present, a court can rely on the institution's claim of past violations as making out a sufficiently compelling interest for the use of explicit racial classifications. ${ }^{174}$

reliable). As she notes, these considerations may justify dispensing with a contemporaneous findings requirement and allowing the existence of a past violation to be an issue litigated if and when the racial preference is challenged. See id. at 1856-57 (O'Connor, J.); see also supra text accompanying note 96.

174 The principles of institutional competence developed in this comment have implications not only for discerning the legitimacy of the government's interest in a remedial affirmative action plan, but also for the exactness with which a plan must meet that objective. Although a majority of the Justices now apparently require "narrow tailoring" in an affirmative action program, see Wygant, $106 \mathrm{~S}$. Ct. at 1846 (Powell, J., joined by Burger, C.J., Rehnquist and O'Connor, JJ.); id. at 1857 (White, J., concurring), the Court's precedents seem to delineate different levels of means-end scrutiny for different government bodies: the congressional plan at issue in Fullilove was held to a much looser fit requirement than the school board plan tested in Wygant.

Competence principles help explain this difference in two ways. First, the appropriate level of scrutiny will depend in large part on the extent of a body's authority. As a matter of judicial power, the deference accorded to bodies with extremely strong sources of authority, see supra notes 118-33 and accompanying text, extends not only to the need for findings, but also to the closeness with which the plan is tailored. In addition, if the body has authority to attack less particularized forms of discrimination, such as the effects of past private discrimination, see supra note 103 and accompanying text, means-end scrutiny necessarily becomes more circumspect. More general discrimination is necessarily remedied in more general ways.

Second, competent bodies may also deserve less searching means-end review because such bodies are unlikely to be motivated by illegitimate ends. Like the inquiry into the importance of the government's interest, means-end scrutiny is primarily a way of discerning whether a racial preference is impermissibly motivated. When an institution is judged competent to implement a race-conscious remedial plan, the court has already done much more than rely on the institution's bare articulation of a compelling government interest in 
This approach makes it possible to generalize about the competence of different government bodies and the extent of findings they must make to legitimate their adoption of a remedial plan. State legislatures, like Congress, have characteristics which indicate a high degree of reliability in finding past violations; the courts should not require particularized findings before judging them competent to adopt such plans. Local representative bodies share some of these characteristics, though to a lesser extent, and should therefore be required to make somewhat more particularized findings. Nonelected government administrative agencies may also be competent, but in most situations only after compiling much more specific findings.

Mark S. Kende

remedying past discrimination-the institution has been judged competent because it actually has made reliable findings of past discrimination. This inquiry goes much further to uncover impermissible motives than does the court's normal inquiry into the presence (i.e., bare articulation) of a compelling government interest. Hence, a court need not look as closely at the means-end fit in order to validate a competently adopted remedial plan. 